doi: $10.19090 / \mathrm{i} .2020 .31 .150-182$

UDC: $050 " 18$ "

\author{
ÁGNES TAMÁS \\ University of Szeged, Department of Modern Hungarian History \\ tagnes83@yahoo.com
}

\title{
MOCKING NATION BUILDING AND IDENTITY. AN ANALYSIS OF CARICATURES IN HUNGARIAN, ROMANIAN, SERBIAN, AND SLOVAK SATIRICAL PERIODICALS IN THE MID TO LATE NINETEENTH CENTURY*
}

\begin{abstract}
This paper aims to present a comparative analysis of caricatures published in Hungarian (Üstökös, Borsszem Jankó), Serbian (Bič, Vrač pogađač), Romanian (Gur'a Satului), and Slovak (Černokñažnik) satirical press in Hungary in the second half of the nineteenth century. The depth of the connection between identity, nation building, and humour will be demonstrated. Theories of nationalism often emphasise the primacy of the role of the press and of print media in nation building processes. To investigate this, humorous printed sources have been selected. The comparison utilises and complements Anthony D. Smith's definition of the ethnic core and reflects on Christie Davies' theory of ethnic humour. Tethered by these concepts, the analysis of the caricatures investigates the following aspects: names for the Self and the Other, elements of culture and tradition (languages, habits, religions, supposed characteristics, clothing and bodily features), symbols of the Self and the Other, historical memories and myths of the common ancestry of the Self and the Other, and the definitions of "our" vs. "their" territory and homeland. This analysis reveals that the stereotypes observed in satirical magazines and the images of the Other and of the Self depicted through the use of humorous or ironic techniques can be effectively distinguished and connected to the nation building process and to the process of shaping "enemies".
\end{abstract}

Keywords: nationalism, nation building, caricatures, satirical magazines, mocking "others".

\section{Introduction}

$\mathrm{T}$ The process of nation building in East Central Europe does not seem to have been completed during the nineteenth century, which is known as "century of nationalism". In his study on the development of national movements of small nations, Miroslav Hroch emphasises that late twentieth century-and even early twenty-

\footnotetext{
* This research was supported by the project nr. EFOP-3.6.2-16-2017-00007, titled Aspects on the development of intelligent, sustainable and inclusive society: social, technological, innovation networks in employment and digital economy. The project has been supported by the European Union, co-financed by the European Social Fund and the budget of Hungary.
} 
first century - nationalisms are comparable to the period of the rise of nationalism and to the events of the nineteenth century. ${ }^{1}$ Thus, it is essential to investigate the development of nations and nationalisms in this region. Hroch also points out that "at the moment we have an overproduction of theories and a stagnation of comparative research on the topic". ${ }^{2}$ Taking this into account, this study attempts to present a comparative analysis, partly because comparative methodology may help to reduce my own ethnocentrism. By evaluating phenomena through comparison, the researcher can maintain a certain distance from the identity being analysed. Romanians, Serbs, and Slovaks were chosen as national groups for analysis because of their large numbers and because of their elevated political engagement. Each of these national groups were subject to the Magyarisation processes of the $1890 \mathrm{~s}$. The country's national minority groups rejected frequent representations of Hungarian culture and history through the Hungarian millennial festivals (1896), and opposed the rise of Hungarian nationalism. The increasing pressure of Hungarian nationalism strengthened a similar chauvinism within the non-Hungarian political elite.

There exists a long tradition of studying ethnic jokes: Christie Davies published his first work on this topic in 1982, and since then many researchers have utilised his insights. Unlike this paper, which deals with the visual element, Davies analysed textual stereotypes about ethnic groups; however, his findings will nevertheless be discussed. He stressed that the most common joke scripts about ethnic groups involve stupidity and canniness. ${ }^{3}$ Such jokes have a long history and are connected with modernity. ${ }^{4}$ However, as Takovski articulated when analysing the humour of the Balkan states, ${ }^{5}$ ethnic jokes contain both (1) universal scripts and (2) scripts connected to an ethnic identity. The first type, (2a) the truly ethnic jokes, mock important elements of identity (e. g. language, habits, or history). The second type is (2b) "quasi-ethnic humour" in which non-ethnic markers such as aggression are "ethicised". ${ }^{6}$ This paper will show that all of these categories can be seen in the caricatures and captions printed in the selected corpus.

Additionally, modernist theories of nation building will also be utilised as a platform for examining caricatures and captions. Although all theoretical works can be criticised, Anthony D. Smith has listed elements of nation, and of national identity. Thus, the occurrence of these elements in the selected caricatures may be scrutinised. ${ }^{7}$

This investigation aims to compare the image of the Other in caricatures printed in the $1860 \mathrm{~s}$, the $1890 \mathrm{~s}$, and at the turn of the century in Hungarian (Üstökös [Comet], Borsszem Jankó [Jonny Peppercorn]), Serbian (Bič [Whip], Vrač pogađač [Magician]), Romanian (Gur'a Satului [Village Gossip]) and Slovak (Černokňažník [Wizard]) satirical magazines. ${ }^{8}$ This study aims to collect stereotypes of Hungarian caricatures about non-

Hroch 1993: 20 .

Ibid. 4.

Davies 1990: 10, 82.

Ibid. 132., 135.

Other authors criticized the theory as well; see Laineste and Fiadotava 2017, Laineste 2005: 21.

Takovski 2018: 72.

Smith 2000 .

List of comic papers and analysed volumes with place of publication in the analysed periods:

(Az) Üstökös: 1868-69, 1890-91, 1895-96, 1898-99 (published in Budapest in the 1860s with the title Az 
Hungarian national minority groups and, conversely, the prejudices made explicit in cartoons created and printed by non-Hungarian national minority groups. The visual methods and the humorous and ironic scenes in the caricatures through which the caricaturists made fun of the Other will then be analysed. The way the construction of nationhood is reflected in the caricatures of comic papers will then be further examined. Connected to this aim is the question: How and through which stereotypes were "us" and "them" segregated in the depictions of these caricatures? Stereotypes belong to the collective consciousness; thus, they are elements of shared beliefs, attitudes, and prejudices about the Other. An evaluation of the depiction of the Self is also necessary to enable the researcher to observe the differences between the visual methods used to represent the "enemy" and those employed for the group considered "us". Furthermore, the modification of national stereotypes that paralleled strengthening nationalism throughout these decades will also be scrutinised. Additionally, the limited linguistic aspect of the caricatures, names, and languages of the speakers will be assessed along with their visual features, as this facet is closely linked to national stereotypes.

\section{Historical reasons for choosing the volumes of satirical magazines}

This investigation was carried out using caricatures depicting characteristic stereotypes from two periods: the period after birth of the Austro-Hungarian Monarchy (1868-1869) and the period during the late nineteenth century crisis of the Dual Monarchy (1890-1902). The satirical press flourished in the Austro-Hungarian Monarchy from the beginning of the 1860s, which marked the beginning of a more open political milieu that lasted until World War I. The first two years after the Austro-Hungarian Monarchy (186869) was founded are interesting in several respects, despite the fact that fewer satirical magazines were published at this time than at the end of the nineteenth century. After the Austro-Hungarian Compromise of 1867, the Hungarian national movement celebrated its first victory following the defeat of the Hungarian Revolution of 1848-49 and the Germanising trends of neo-absolutism. Additionally, the Compromise rendered the "nationality question" an internal Hungarian and Austrian issue. Emperor Franz Joseph sanctioned the 1868 Hungarian Nationalities Law, which contained passages about the equality (Gleichberechtigung) of individuals as a major concession to the liberal Hungarian political elite; however, the national minority groups were not officially accepted as nations (with the exception of the Croats). The Hungarian elite's liberal ideology did not deem it necessary to grant collective rights to national minority groups once their basic civil rights had been provided. In theory, the Nationalities Law enabled national minority groups to use their own language in the lower levels of administration and jurisdiction, in primary and secondary schools, and in church-related matters. Nevertheless, the law in practice only

Üstökös, but in the 1890 s as $\ddot{U}$ stökös).

Bič: 1890 (published in Belgrade).

Borsszem Jankó: 1868-69, 1890-91, 1895-96, 1898-99 (published in Budapest).

Černokňažník: 1890-91, 1895-96, 1898-99, 1901-02 (published in Sv. Martine).

Gur'a Satului: 1868-69, 1901-02 (published in Arad).

Vrač pogađač: 1896, 1898, 1902 (published in Zagreb 1896-1902, after that [1902-1914] in Novi Sad). 
worked to a lesser extent; hence, one of the main demands from non-Hungarian politicians was for the Hungarian government to comply with the Nationalities Law and to agree to implement the rights it had granted.

Instead of territorial autonomy, attaining cultural autonomy became the principal aim for national minority groups, and this included education in their language at universities, multilingual administration and jurisdiction, a free non-Hungarian press, and the founding of non-Hungarian associations in which ethnic groups could nurture their own literature, culture and history. The national minority groups' territorial demands tended to reflect the concept of reorganising county borders to reflect ethnic enclaves, which would have simplified the multilingual administration. The Hungarian political elite objected to these demands and argued forcefully that such claims endangered Hungary's territorial integrity. Conflicts and actions that created friction became more frequent in the $1890 \mathrm{~s}$ when the millennial celebrations and exhibitions for the anniversary of the Hungarian conquest (Landnahme) were organised in 1896.

\section{Sources and methods}

This analysis was not conducted on political leaflets, speeches, or literary works. A more common genre was selected for investigation: caricatures in satirical magazines. For the purposes of this study, a broader concept of caricature was utilised; it is not defined as simply a portrait but rather in more general terms as a humorous or satirical picture or an ironic or entertaining depiction of everyday life. ${ }^{9}$ The significance of such depictions can be legitimised by the fact that the symbols used in caricatures are simpler and more obvious to the readers than the symbols employed in literary or academic writings. ${ }^{10}$ The intelligentsia of any period of time have always found images to be more effective weapons than words. This characteristic of caricatures is essential because the population was becoming increasingly literate during this period, albeit at different speeds depending on the national group. The stereotypes in humorous texts could be reinforced with visual representations, which could be decoded more quickly. Also, the visual elements were also (partly) comprehensible to those who (still) could not read.

This investigation utilises more Hungarian satirical magazines because they were published on a regular basis; the Hungarian government had made it more difficult nonHungarian news outlets to publish. Unlike Hungarian satirical periodicals that were published weekly, non-Hungarian humorous publications were printed only once or twice a month. Thus, fewer caricatures from Serbian, Slovak, or Romanian cartoonists are available in the editions analysed here. Nevertheless, these caricatures are also worth analysing because, despite their fewer numbers, they belong to the same genre of caricatures.

These satirical magazines proved to be adequate sources from which to uncover national stereotypes because caricaturists and readers (who also sent their ideas for caricatures to editorial offices) presented and viewed national groups through similar schemata. Therefore, the Hungarian and non-Hungarian opinions about each other can be

\footnotetext{
Langemeyer ed., 1984: 7.

$10 \quad$ Fuchs and Kraemer 1901: 11.
} 
plausibly reconstructed, and the process of constructing an "enemy" can also be seen alongside the course of nation building. Moreover, the caricatures both reflected and influenced readers' viewpoints. It is impossible to measure the effect of the caricatures, but it is certain that the readers of satirical magazines expressed thoughts about these caricatures in, for example, their diaries or personal letters. ${ }^{11}$

According to Smith, modern nations are rooted in ethnic cores. Most stereotypes evincing the close connection between (negative) stereotypes about the Other and nation building in the caricatures analysed here can be grouped into the elements of Smith's concept of the ethnic core. In their graphic art, the caricaturists mocked the very features modern theoreticians of nationhood have attached importance to from the point of view of nation building. Therefore, the comparison effected in this paper is accomplished by using and completing the definition of the ethnic core, which includes the following components: ${ }^{12}$

1. Names, self-denominations, and the language of the Other

2. Elements of the culture and its traditions (habits, religion, supposed characteristics, clothing, and bodily features)

3. Symbols of the Self and the Other

4. Historical memories and myths of a common ancestry of the Self and the Other

5. A definition of "our" and "their" territory and homeland.

The inequality of a group and not acknowledging its self-determination can be easily viewed through nicknames and mockery of the Other's language ${ }^{13}$ hence, this analysis begins with the names for the caricatures given in captions. ${ }^{14}$

\section{Names and self-denominations: the language of the Other}

A self-denomination, or a common name a group gives to itself, is important from the point of view of a national ideology. Hence, Hungarian satirical magazines did not identify national minority groups by using their self-denominations in captions and in other humorous texts. Slovaks were referred to as tót; Serbs were called rácz in the 1860s, but in the $1890 \mathrm{~s}$ they were named szerb or vad rácz (wild Serb); and Romanians were designated by the terms oláh (Wallachs) or rumuny. Since these names stemmed from the Middle Ages, Hungarians used these traditional terms for the other ethnic groups while the "new" names (Serb, Romanian, and Slovak) did not appear until the nineteenth century. These terms of feudal origin remained unchanged in the Hungarian press despite protests from the Romanians presented in their memoranda. The Hungarian political elite considered itself to be a historical group that had existed in the form of a nation from the beginning of humankind. This privileged and influential assemblage saw the "new" nomenclature as both illegitimate and concurrent constructions by non-Hungarian elites. Personal names can seldom be found

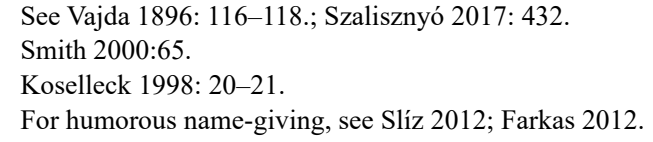


in the captions from these Hungarian publications. When they were used, these names were typically recorded as forenames (e.g. Slovak names such as Misu, Jano or Gyúró ${ }^{15}$ ), and tend to appear in shortened form to show the non-Hungarians subordinated position. ${ }^{16}$

The Serbian and Romanian satirical magazines analysed here mention Hungarians as magyar or magyar-ember (a male Hungarian). In the Romanian paper Gur'a Satului, typical Hungarian forenames used in the captions included Pista, Laczi, and András. ${ }^{17}$ Various options can be seen in the Slovak publication: it calls the land and its inhabitants magyar, but the forenames and surnames can be divided in three groups:

a) Forenames typically connected to Hungarians, e.g. Pista. In the nineteenth century, István (shortened form, Pista) was also one of the most popular names according to birth records. ${ }^{18}$

b) "Magyarised" names of assimilated Jews (appearing in the order of the Hungarian surname first and forename second): Harangfy Samu, Diamant Mór, Gyémántossi Árpád. These names are not unique; similar names denoted assimilated Jews in the Hungarian satirical press as well. ${ }^{19}$

c) Nicknames typically associated with the average Hungarian: Kutaláncoš (a distorted version of the Hungarian phrase láncos kutya or dog on a chain). ${ }^{20}$

According to statistics, most assimilated Jews Magyarised their names in the $1890 \mathrm{~s} .{ }^{21}$ This practice was also frequently mentioned in the satirical magazines as a recurrent and eye-catching phenomenon for the contemporary Hungarian populace. In the non-anti-Semitic Hungarian comics, the authors did not mock the assimilation of the Jews. Conversely, some of the caricatures and depictions published in Černokñažník and presented in Serbian satirical magazines at the end of the nineteenth century, and primarily at the beginning of the twentieth century, identified Hungarians with assimilated Jews. These references contained all the negative stereotypes associated with Jews. Furthermore, they mocked the close connection between the assimilation of the Jews and the growth of the Hungarian population in the kingdom as result of assimilation. The end of this period was also an era of anti-Semitism both in Hungary and across Europe, and a time when Jews voluntarily assimilated into the mainstream.

Mostly through the 1860s, Hungarian cartoonists made fun of the languages of minority groups in captions. Serbian names always ended with -ics/-vics and their language included words that also ended in -ics/-vics. Romanian was another language that was often mocked: Romanian endings were typical (-ulu), like Serbian, which was considered funny and was ridiculed. ${ }^{22}$ This period also saw the "Latinisation" of the Romanian language,

Üstökös, 27 September 1891, 154.; Üstökös, 2 August 1896, 291.; Üstökös, 2 November 1890, 211.

For names in Hungarian satirical magazines, see Tamás 2014: 189-224.

Gur'a Satului, 2 November 1869, 148.; 25 February 1868, 24.; 27 March 1902, 13.

Černokňažník, 25 March 1902, 17.; Hajdú 2003: 559-569.

Černokňažník, 25 July 1895, 53.; 25 May 1901, 36.; 25 May 1901, 37.; Tamás 2012: 41-48.

Černokňažník, 25 April 1895, 29.; 25 August 1895, 60.

On "Hungarianisation" of names see Maitz, Farkas 2008: 163-193; Farkas 2009: 375-384.

Borsszem Jankó, 18 October 1868, 575.; Borsszem Jankó, 12 April 1868, 173. 
which was closely connected to the Daco-Romanian continuity view being unacceptable for Hungarians. Thus, Hungarian authors and artists chose to target the Romanian language with irony. The Daco-Romanian continuity view holds that Romanians are the descendants of the Dacians and the Romans, and that they had lived in the Carpathian Basin before the Hungarians. Therefore, Romanians could claim historical rights to the region, but Hungarians could not.

One supposed feature connected to the Hungarian language in non-Hungarian satirical periodicals was that the Hungarians used a lot of expletives. This view was degrading to the Hungarians and their language, and stood in contrast to the Hungarians' opinion that their language was at the top of an imaginary hierarchy of the languages within the Kingdom of Hungary.

\section{Cultural and human characteristics through each other's eyes}

The caricatures in these satirical magazines were built on earlier stereotypes of national characterisations, folksongs, and proverbs that appeared not only in satirical publications and literary works of national romanticism but also in calendars and paintings. Thus, these stereotypes of non-Hungarians were familiar to observers. However, new aspects in the images of the Other can be discovered in the Hungarian satirical periodicals published at the end of the nineteenth century.

In caricatures, clothing and physical features are the most obvious since they represent supposed inner characteristics through symbols or captions. It would be pertinent to first demonstrate the depiction of the Self in the Hungarian satirical press to provide a sense of the distinctions drawn in the representation of national minority groups. Caricaturists tended to draw positive images of Hungarians: tall, moustachioed men standing upright and warlike. The illustrations suggested strength and chivalry, and the men were often depicted being accompanied by beautiful Hungarian women. The Hungarian national costume was an important element of Hungarian national identity. In the nineteenth century, it symbolised Hungarian resistance against the Habsburgs and the people's declaration of independence. At the end of the century, Hungarians can be recognised in caricatures as gigantic, masculine wrestlers or athletes, which accompanied the spread of amateur sports and the emergence of the idea of the Olympic Games. ${ }^{23}$

In the Hungarian satirical press, non-Hungarians are mostly depicted as shorter than Hungarians, symbolising the contemporary idea of a social and "national" hierarchy. In nineteenth-century Hungarian public opinion, only Hungarians (and Croats) were considered to be nations since these two groups shared a common language and culture, and had also been independent medieval states. This status stood in contrast to the position of other ethnicities in Hungary, who were only considered to be "national groups". The national minority groups considered themselves to be natural nations, and they fought for acknowledgement as such.

In all of these satirical magazines, Hungarians and the national minority groups were distinguished from each other through attire that was considered typical of their populations.

23 Üstökös, 25 August 1895, 405. 
Serbs were recognisable by their tasselled fezzes, Slovaks by their wide hats, Romanians by their fur caps, and Hungarians by their traditional national costumes. The national minority groups were depicted similarly in Borsszem Jankó and Üstökös at the end of the nineteenth century: mostly in torn clothes, wearing sandals, and traditionally attired in folk costumes rather than the modern clothing customarily worn at the end of the nineteenth century by their largely urban readership. This method was one of the visual tools of mockery, but it also suggested the national minority groups' impoverishment and lower social status.

The differences in the way national minority groups were portrayed can also be noted through their features and postures. In the second half of the nineteenth century, the bodily features of these national minority groups as being deformed can be seen in the Hungarian satirical press, and was first seen in depictions of Romanians. In the pictorial representations of Romanians, their posture was presented as more unnatural, the limbs were disproportional, and the body seemed amorphous. They were given increasingly deformed facial features. Their hands and feet were unduly large, their hairy arms and legs were very thin, and their hair was matted. The images of the Romanians at the end of the century appeared to be less human than those of the Hungarians (figure 1). The satirical press made fun of Romanians via illustrations with amorphous bodies or misshapen faces. The Hungarian satirical press at the time referred to Romanians in a very negative way because much of the population felt threatened by the Romanian elite's political demands. Nevertheless, Romanians appeared less frequently to be aggressive in pictorial representations than in textual characterisations. In texts, Romanians were also described as wild, violent, and cruel.

The most characteristic generalisation of Serbs and Romanians was to denote them as bellicose and aggressive. The roots of these depictions can be found in historical events and in collective memories of those occurrences. The Serbians and Romanians had killed innocent, unarmed Hungarian civilians in Transylvania and in Southern Hungary during the revolution in 1848 and $1849 .{ }^{24}$ Thus, Serbs were often depicted with blood-thirsty eyes and daggers that symbolised unfair combat. In contrast, Hungarians were always illustrated with a sword in hand as a reference to their legendary chivalry. Serbs were pictured in caricatures as behaving in an uncivilised, barbaric manner and were always fighting. For the contemporary mainstream, the assassination of the crown prince of the Dual Monarchy, Franz Ferdinand (28 June 1914), in Sarajevo justified these stereotypes and validated the depravity of the Serbs. However, bravery and being a good soldier were important aspects of Serbian national identity, and this aspect was ridiculed by Hungarian caricaturists.

Slovaks were not depicted as bellicose; they were drawn with round faces and sometimes with slovenly, shoulder-length hair. In one of the depictions, they were portrayed as destructive and anti-national by destroying important Hungarian administrative buildings. ${ }^{25}$ This representation came from the fact that many Slovaks working in Hungary were employed in the construction industry. Other cartoons and captions attributed to them cowardice, stupidity, or illiteracy. These traits were also used to characterise the Romanians

24 E.g. in text Üstökös, 11 December 1869, 405.; Borsszem Jankó, 23 July 1899, 6.; in caricature Borsszem Jankó, 12 April 1868, 165.

25 Borsszem Jankó, 15 March 1891, 3. 
in other caricatures. In one caricature, the Slovaks were depicted as never having seen a surveyor, and thus as falling prey to the trap of an engineer shouting "Attention! It will go off!" 26 The Slovaks were portrayed as running away, believing the item to be a gun.

The opposition of the image of the Self and that of the Other in the 1890s can be similarly reconstructed in a Slovak satirical magazine. The representation of the Slovak peasant differed from that of his Hungarian counterpart. Figures of the latter retained the human features of his body and were depicted in Hungarian national costume. However, the spurs on their boots were parodied, and their posture and physical features would typically be associated with Jews, or they were depicted as overweight and aristocratic. Jews could be recognised primarily by bad posture, bow-leggedness, and large ears and nose. Conversely, Slovak nationals, in contrast to the "Christ killers", appeared to be peaceful and nonviolent. ${ }^{27}$ The appearance of Jews in the caricatures ignited negative feelings and emphasised the negative stereotypes that had existed since antiquity (e.g. dishonest businessmen, untruthful in character, heartless usurers, and later on as gamblers on the Stock Exchange). The caricaturists projected these negative stereotypes onto mainstream Hungarians by depicting Hungarians as Jews or as accompanying Jews. However, this manner of representation was also attached to the self-image of the Slovaks. The Slovak self-image at the time incorporated a strong anti-Semitism that was projected onto the Hungarians due to the Hungarian elite's close relationship to the Jews. This detail also became a part of anti-Hungarian rhetoric in the Slovak satirical magazine. ${ }^{28}$ Jews symbolised contemporary modernity as well; therefore, the element of anti-modernity versus the attribute of being an ancient nation can be noted in Slovak national propaganda in Černokñažník.

Hungarians were pictured in the Serbian Vrač pogađač at the beginning of the twentieth century in a manner very similar to the depictions of the Slovak magazine: Hungarians could be seen as Jews in Hungarian national dress wearing extra-large spurs. Boots with oversized spurs, large moustaches, and Hungarian national costumes, as illustrated in Černokñažník, were also typical in the 1890s. Hungarians could be viewed in most depictions not only as Jews, but as also being violent. This detail was usually depicted through the illustration of an axe, suggesting aggressive behaviour. It is worth observing that, similarly to the Hungarian publications in which Serbs and Romanians (rather than the "us" group) were depicted as violent, in the non-Hungarian satirical magazines, Hungarians were the ones represented as the violent unit. Similarly, both the Hungarian and non-Hungarian satirical magazines pictured the Other carrying out-of-date rather than modern weaponry.

Jews did not appear with positive attributes in the Romanian satirical magazine either ${ }^{29}$ but the illustrators did not associate these characteristics with Hungarians. In Gur'a Satului, Hungarians were also depicted in their national costumes. Thus, it may be concluded that Hungarians appeared in the non-Hungarian comic papers in national costumes, wearing boots with spurs, and in the clothing of the nobility, which emphasised an association of the Hungarians with the theme of oppression. This link with subjugation

\footnotetext{
Üstökös, 20 July 1890, 28.

Depictions of Jews had significant similarities across Europe, see Fuchs 1921.

Szabó 2013: 212-229; Krekovičová, Panczová 2013: 462-487.

Pădurean 2013: 488-514.
} 
also surfaced through other motifs in medieval Hungarian society that Slovaks, Romanians, and Serbs were supposedly mostly peasants and the Hungarians were land owners (or at least that most of the land owners were conscious of being Hungarian nobles). Thus, these stereotypes reflect the social hierarchy of the times before the modern, civic state (1848).

The national minority groups appeared in the Hungarian comic papers also, according to their former status as serfs or peasants. The nickname for Hungarians mentioned above, Kutaláncoš, also referred to this perceived Hungarian oppression. Hungarians were regarded and portrayed by the national movements as feudal oppressors. This aspect could be connected to the supposed financial oppression associated with the Jews. Before 1895, when the Jewish religion became an officially recognised faith in Hungary, it was rare in Černokňažnik for Hungarians to be represented with feudal and Jewish attributes in the same picture, but afterward it became more common.

In contrast, the depictions of non-Hungarians in the non-Hungarian press were simpler and undistorted. In the Romanian, Serbian, and Slovak satirical press, the national minority groups could be distinguished based on their clothing; amorphous bodies or faces were not characteristic. In the non-Hungarian satirical magazines, the image of the Self corresponded to that of a friendly peasant. In these publications, the national minority groups were intentionally drawn as being of similar height, were given identical body shapes, and were shown to suffer in the same way from Hungarian "despotism". In these non-Hungarian comics, the national minority groups were represented as hard-working people working the land and suffering under tyranny, whereas Hungarians were pictured as dancing, drinking, and being lazy rather than working. Nevertheless, it was the Hungarian state that required the Magyarisation of non-Hungarian minority groups.

\section{The animalised Other}

Animalising the enemy, or the Other, is an ancient weapon used by caricaturists to separate "us" from "them". Classical myths abound with animals and half-human, halfanimal creatures that symbolise human characteristics. These myths and their interpretations were well known, but it is, of course, impossible to presuppose that every reader in the nineteenth century understood animal symbols in the same way. Interestingly, animal symbols can mostly be seen in the Hungarian satirical magazines.

In his work on the concept of enemy, Koselleck explains how, during the nineteenth century, the idea of the non-human being changed from having a religious significance to a political meaning. In the eighteenth century, the religious meaning of "pagan" was attached to the term non-human being; in the nineteenth century the signification was altered to express a subordinate status. This change could also be seen in the Hungarian satirical magazines, but the sentiment was not apparent in the 1860s. The faction of humans appearing as non-humans became annihilable, and this group could be held guilty of what it was not responsible for, such as its language or its nationality. ${ }^{30}$

The Slovaks were depicted this way at the end of this period as half-human, halfanimal and monkey-faced, suggesting an analogy with the delineation of Czechs in Austrian

$30 \quad$ Koselleck 1997: 73., 77; Koselleck 1998: 21. 
satirical magazines. ${ }^{31}$ In Christian iconology, the monkey symbolises ugliness, amorality, and unscrupulousness; thus this animal can be used to caricature human beings guilty of sins, primarily those of avarice or lust, and who bewitch humankind. This signifier automatically leads to associating such people with the Devil. In Cesare Ripa's Iconology, the monkey is a symbol of brazenness. ${ }^{32}$ At the end of the nineteenth century, other possible associations established with the monkey also need to be considered. Charles Darwin's $O n$ the origin of species by means of natural selections: or the preservation of favoured races in the struggle for life was published in Hungarian in 1873. Darwin explained species' struggle for survival; however, he also expounded on a theory of evolution that was in opposition to Church doctrine. In this context, the depiction of a person with the face of a monkey implied an extra signification that the Slovaks were not fully developed humans; hence, they were not equal to the Hungarians and were a subordinate species, a term made more insidious by its Darwinian association. The contemporary Hungarian intelligentsia certainly knew about and discussed Darwin's theories in the press. If a type of human being was not depicted as equal to the Hungarians, the illustration of inferiority suggested more than being subordinate; it also implied their demands were not legitimate.

Other animal symbols were also common: Romanians were depicted as small, awkward, and rather harmless dogs fighting the Hungarian lion, the king of animals. Slovaks were portrayed as frogs croaking in the Pan-Slavic swamp. Additionally, the Serbs, Slovaks, and Romanians were depicted as an assemblage of small barking dogs, monkeys, or rats. In other words, the minority nationals were described as animals that were disgusting, ugly, or very small in stature in contrast to the Hungarian lion. Thus, the national minority groups symbolised through these animals were subordinated to the Hungarians. According to Ripa, the frog signifies imperfection, which one can understand according to Darwin's theory and according to the manner in which the Hungarians at the time thought about the Slovaks. ${ }^{33}$ In one cartoon, the Serbian and Romanian figures are shown to be a nuisance to a sleeping lion representing the Hungarian nation, while the personification of the Slovaks steps aside (figure 2). The monkeys anger the king of the animals, which reacts as Hungarians did to national agitations. The lion in this caricature represents the Übermensch, thus demonstrating the power of the Hungarian state. The lion was depicted similarly in a cartoon in which he is illustrated as standing in front of an angry pig symbolising the Serbs (figure 3). Serbs were symbolised as pigs partly because of ongoing trade conflicts between Hungary (the Monarchy) and Serbia over the import of pigs from Serbia. The import of Serbian pigs went against Hungarian agricultural interests. From the beginning of the 1890s, several trade crises occurred between Hungary and Serbia, and the most notorious of these was the "pig war". In the Serbian satirical press, pigs appeared in connection with the trade crisis and depicted the process of reconciling Hungarians with the pigs. ${ }^{34}$ According to Ripa, the pig is a symbol of idleness and ignorance. Ignorance is a trait

\footnotetext{
Tamás 2014: 128-132.

32 Cooper 1986: 10.; Ripa 1997: 535. This Iconology was well known to the contemporaries, since it was published in most European languages; the first edition appeared in 1593. The explanations of the symbols were based on Egyptian, Greek, and Roman mythology and on the Bible.

33 Ripa 1997: 282.

34 Bič, 5 August 1890, 1.
} 
that also appeared in textual terms in the Hungarian satirical magazines. These caricatures with animal symbols made fun of the demands by national minority groups and, by extension, of the groups themselves.

Fewer animal symbols were found in the non-Hungarian press than in the Hungarian papers. The only representations of animals appear when Hungarian chauvinism is represented by a barking dog being soothed by a Slovak depicted as a small deer or in the form of a snake with Jewish attributes. ${ }^{35}$ This symbol points to the dangers of exaggerated nationalism: for example, in Vrač pogađač, Hungarian chauvinism was symbolised as a toad, which according to Ripa signifies greed. ${ }^{36}$

\section{Opinions about Magyarisation: Hungarian aggression}

"Forceful Magyarisation" was represented and critiqued in the non-Hungarian satirical press through discrete symbolic scenes. For example, in one depiction in Vrač pogađač, the Hungarian figure is illustrated as attempting to catch a fish labelled as "Nationalities" with a fishing-net labelled "Magyarisation"; in another, a Hungarian is depicted pouring the "Hungarian language" into the head of a ram with the help of a funnel while a Hungarian Jew attempts to hold the ram still. ${ }^{37}$ All of these scenes mocked the idea of Magyarisation through different visual means and suggested the impossibility of the Hungarians' efforts: it is not easy to catch fish, and no one can learn a language in the way in which it is presented in the caricature. In another cartoon, the Hungarian prime minister, Kálmán Széll (1899-1903), is illustrated trying to ram a wooden pole labelled "Nationalities" (figure 4) into the ground; however, the caption informs the readers that he has failed. A depiction in Černokňažník is similar: an axe held by Dezső Bánffy, the former prime minister (1895-99), is broken and he cannot chop down a tree trunk labelled "Slovaks". ${ }^{38}$ Both Hungarian prime ministers were pictured as behaving aggressively towards national minority groups, as represented by their axes and by the scenes themselves: they are shown attempting to destroy something. Figuratively, the cartoons were meant to drive home the mainstream desire to eliminate national minority groups considered to be enemies of the homogeneous Hungarian national state.

Bánffy was openly chauvinistic, and his name was linked both with the department of the prime minister's office against national agitation (1895) and to the law on the Magyarisation of place names (1898). Vrač pogađač criticised Bánffy, the Hungarian voting system, and the Magyarisation of Jews in another caricature. In this cartoon, Hungarian chauvinism was symbolised as Bánfy pasha sitting next to a house with "Hungarian chauvinism" written on its side. This illustration implied supposed similarities between the despotism of the Ottoman pashas and the Hungarian prime minister, Dezső Bánffy. ${ }^{39}$ In this caricature, one could also see Constitutionalism depicted as a woman being beaten by Hungarians and assimilated Jews

\footnotetext{
Černokňažník, 25 June 1902, 41.; 25 November 1902, 84.

Vrač pogađač, 28 February 1898, 43. Ripa 1997:53.

Vrač pogađač, 1 March 1902, 27.; 30 May 1898, 116.

Černokñažník, 25 July 1898, 49.

Vrač pogađač, 30 October 1896, 237.
} 
criticising the Hungarian state order. The flag in this caricature was labelled as "false liberalism", which served to question the liberalism of the Hungarian government. The picture further referred to criticism of the Hungarian voting system by non-Hungarians: although Jews could vote, non-Hungarians were excluded from the ballot despite their growing numbers and could not cross the barrier of the labelled "freedom of elections". Hungarians were depicted as drunken men lying on the roadside or scuffling. This kind of depiction is not a coincidence: various kinds of wide-spread electoral fraud (e.g. bribery and harassment) were common during the Hungarian elections of this period.

Magyarisation was also strongly satirised in another Slovak caricature titled Magyart izélö masina (Machine for Producing Hungarians). Hungarians were pictured inserting human figures into a machine from which emerged Hungarians with Jewish attributes. The depiction mocked the increasing numbers of Hungarians through the assimilation of the Jews and the forced Magyarisation (figure 5) of the populace. The caricature also ridiculed the data reported by the 1900 census in Hungary. According to these data, the proportion of Hungarians in the Hungarian Kingdom was only around $50 \%{ }^{40}$ The ironic caption read:

\footnotetext{
"This is what the modern Hungarian state's machine for multiplying Hungarians is called. It is very simple and works beautifully. Just put refuse of any nationality into the machine, and from it you will get people who have been painlessly reborn and enlightened, just as the picture shows. We recommend this to all nations with too few children. By Sél \& Co., on sale in Judapest."
}

This text exemplified the caricaturist's opinions of how Hungarians saw non-Hungarians (as the "refuse of any nationality"). The non-Hungarian and Austrian satirical magazines and the Hungarian anti-Semitic press satirised Budapest as Judapest because of its elevated percentage of Jewish inhabitants. This description of assimilation as a machine was conceived of by Béla Grünwald, who claimed in his famous 1878 work A Felvidék. Politikai tanulmány (Upper Hungary: A political study) that secondary schools were like machines Slovak boys could be placed in and Hungarian men would emerge from the other end. The Slovak caricature, drawn ten years after Grünwald's death, may be interpreted as a response to his statement and also, to a certain extent, the Slovak National Party's propaganda against Magyarisation. The Slovak National Party gave up its political passivity in 1901 and became an opposition party in the Hungarian elections of $1901 .^{41}$

In an earlier Slovak caricature, a Hungarian was illustrated holding a plate with small non-Hungarian figures on it and wishing that in another thousand years the non-Hungarians would become such small museum pieces. In other words, the mainstream Hungarian wanted nationalities to disappear or assimilate. ${ }^{42}$ According to the caricature, the Hungarian was shown wishing for the national minority groups to be miniaturised or to be exhibited as figurines, because Hungarians wanted minority groups to become a historical memory and a homogenous Hungarian national state to become reality.

The Romanian satirical magazine also published caricatures about the Hungarians' forceful aspirations. However, a new element-Romanians burying and mourning their long-

\footnotetext{
Illyefalvi vitéz, ed., 1904: 45.

Grünwald 1878: 140.; Holotík 1980: 797.

Černokňažník, 25 August 1895, 60.
} 
desired autonomy - can be observed in them as well. ${ }^{43}$ This was because the Romanian political elite had been forced to give up its demand for territorial administrative autonomy at the end of the 1860s. The motif of oppression can also be seen in Gur'a Satului, but only at the end of the 1860s and in the first years of the Dual Monarchy. These drawings referred to the modified structure of power: In the first picture, the Austrian figure of Michel was illustrated standing on the shoulders of minority nationalities (Hungarians, Romanians, Serbs, and Slovaks); in the second caricature, Michel and Pista were pictured standing on the shoulders of the national groups (Romanians, Serbs, and Slovaks) (figure 6). According to the caricature, all the groups (including the Hungarians) suffered under the Germanisation of neoabsolutism. However, after the formation of the Austro-Hungarian Monarchy, the Hungarians (along with Michel) became the oppressors. The Hungarian figure in the caricature had not learned anything from the failure of Germanisation during the previous decades.

Another cartoon pictured a hat with the label nemzetegység (national unity) and pointed to Magyarisation overriding the representations of the national groups. ${ }^{44}$ The caricaturist attempted to highlight the impossibility of this unity: The conflicts could only be "capped" or covered up by a hat. A visual contrast can also be seen: the figures of the national minority groups are small, while the Hungarian figure is taller and bigger, demonstrating the Hungarians new and powerful position, which immediately became precarious, according to the Romanian point of view. These depictions refer to the two sides' opposing interests at the end of the 1860s: the demand for and the rejection of autonomy, and the beginning of a power reorganisation in Hungary in which the non-Hungarian political elite could not take part.

Conversely, the Hungarian press pointed to civil rights and equality as accorded by law and strongly protested against the suggestion that non-Hungarians were oppressed in Hungary. In an ironic cartoon, for example, representatives of the national groups were shown eating dumplings and carousing, activities that, according to the caption, were denoted as "tyranny" in Hungary (figure 7). Another picture on a similar theme evinced how non-Hungarians in Western Europe imaged Hungarians while also displaying the self-image of the peace-loving Hungarian (figure 8). The message of the caricature was simple: it was a lie that national minority groups were oppressed in Hungary, because, as can be seen, they were happily living in Hungary in a state of comfort (perhaps better than the Serbs and Romanians in their mother countries, which were considered at the time to be poorer).

\section{National symbols and symbols of countries}

Although national symbols are indisputably important elements in terms of the national consciousness, it is rare to find these emblems in caricatures. Since Hungarians were viewed as a nation, they could obviously use their flag, coat of arms, and other symbols (the royal crown and crown jewels). Conversely, the minority national groups could not apply their national emblems freely. In the mid-nineteenth century, these groups began demanding the right to use their national symbols. Although they did not have their own symbols at the

\footnotetext{
Gur'a Satului, 16 January 1868, 4.

4 Gur'a Satului, 3 December 1868, 156.
} 
time, they felt that they should be able use those from their mother countries (Romanian Kingdom, Serbia, or even Russia). The use of these emblems, however, was considered treason at the time by the Hungarians. Therefore, the symbols of national minority groups did not appear in the satirical press to avoid charges of treason, and Hungarian symbols became a rare topic for cartoons, although there were some examples of their use.

A modified Hungarian coat of arms can be seen in an example from Černokñažník. ${ }^{45}$ The caricature fits the pattern of ridicule the satirical magazine used for Jewish assimilation and Hungarian-Jewish relations. The caricaturist drew a Star of David instead of the cross at the top of the Hungarian Holy Crown and in place of the double cross on the shield of the Hungarian coat of arms. He also wrote Jewish names in the fields to symbolise Hungary's rivers. ${ }^{46}$ This modified coat of arms was held by two figures with stereotypically Jewish features. The title of the depiction suggested that the caricature was an ironic depiction of the process of the Magyarisation of the Jews. The Slovaks' fear of assimilation is perceptible in the depiction: the Slovaks believed that, given enough time and the successful assimilation of Jews, Magyarisation could be successful among the other national minority groups as well. The assimilation of the Jews was considered to be a negative example for the Slovaks, even though it had been a spontaneous process in the second half of the nineteenth century, and Slovak integration was also occurring in places such as Budapest. ${ }^{47}$

Nations and national groups have long been symbolised. Moreover, countries are characterised through traditional allegory, often appearing in the form of a woman. In antiquity, Europe was represented as a young woman, and this image was then adopted by the European Christian practitioners of the fine arts. ${ }^{48}$ After the birth of nations, young, beautiful women would become the symbol of countries. Hungaria, Hungary, allegorically appeared as a beautiful young woman (figure 9) in the Hungarian press, just as Serbia did in Vrač pogađač. However, in the Slovak satirical magazine, Austria (Austria) and Hungary (Hungaria) appeared as women, but the visual representation of Hungary in this publication differed greatly from its depiction in the Hungarian satirical press. Hungaria and Austria were shown as old women with deformed faces, Hungaria was illustrated beating the Slovaks, and Austria as beating the Czechs. Slovaks and Czechs are depicted as innocent children, while Pista and Michel smile mockingly (figure 10). They seem pleased that the "mothers" are injuring only their Slovak and Czech children. This symbol, the beating of one's own children, denotes the cruelty of the Hungarian and Austrian oppression of national minority groups.

\section{Satirising prehistory}

As with national symbols, historical memories and genesis myths were not frequent topics in the cartoons analysed here. Only one Hungarian caricature depicted the theory of

\footnotetext{
45 In the Hungarian satirical weeklies, the Hungarian coat of arms and the Hungarian Holy Crown are represented, but in these pictures, they are naturally not sources of humour.

Černokňažnik, 25 May 1896, 33.

Szarka 1995: 60-69.

Ripa, 1997: 399-400.
} 
Daco-Romanian continuity. ${ }^{49}$ In the caricature, two Romanian children are illustrated as being nursed by a wolf (as in the myth of Romulus and Remus) and they are shown rejecting a friendly Hungarian nanny. The children are thus depicted as behaving aggressively without good reason, and their conduct is juxtaposed with the agreeableness of the nanny. It is thus implied that if there are any conflicts, the children must be at fault. They would rather nurse from a wolf than learn Hungarian from their nanny. This cartoon evolved after the Hungarian parliament voted on a law pertaining to nursery schools. According to this law, children living in the areas occupied by national minority groups were required to learn Hungarian in nursery schools. The Romanians actively protested against this rule, which is what was being mocked in the caricature. The Hungarian caricaturist valued Hungarian language and culture, symbolised by the beautiful young nanny, as being more refined than the not so civilised Romanian culture and language personified by the wolf.

Two Slovak cartoons satirised the origin of the Hungarians: one of these depictions was split into four pictures that took an ironic look at Hungarian legends from the age of the Hungarian migrations and conquest. ${ }^{50}$ The Hungarians' barbaric Asian ancestry was ridiculed in other non-Hungarian caricatures as well. The Hungarians appeared with Asian features and living in yurts, as they did many centuries ago. ${ }^{51}$ This representation did not suggest a higher social status, and it did not depict a successful, modern nation. It evinced a huge contrast to the Hungarians' representation of the Self.

\section{The nation state and autonomy}

In equivalence to the symbols and to collective historical memory, a territory where a nation can establish a state is a vital characteristic for nationhood and national identity. Caricatures and texts in the Hungarian satirical press in the 1860 s referred to the national minority groups' territorial demands. However, the typical cartoon about such territorial demands represented the national groups in Hungary as factions wanting to tear the map of Hungary into pieces. In 1868, two pictures were published with this motif but with notable differences. In early 1868 , the Hungarian figure was also depicted as one of the nationalities in the caricature: he was shown trying to tear off his land and protect his territory. In the late 1868 depiction, after the Nationalities Law was finalised, the Hungarian figure was illustrated standing in the middle of the map, trying to prevent the other national groups from pulling on their pieces of the map. ${ }^{52}$ In addition to the Hungarians, the Serbs, Romanians, and Slovaks were also depicted in this caricature: this picture evinced the extent of the likeness with which the nationalities had been depicted in the 1860s and the degree to which this illustration had changed by the end of the century. Maps are one of the traditional methods of outlining territorial demands, not only because they make the demands clear, but also because maps suggest a measure of objectivity. Both the territorial demands and the ironic rejection of the demands seem to be legitimate.

Borsszem Jankó, 8 March 1891, 119.

Černokňažnik, 25 June 1896, 45.

E.g. Černokňažník, 25. November 1895, 85.

Borsszem Jankó, 12 January 1868, 20.; Az Üstökös, 13 December 1868, 394. 
Territorial demands were also satirised through other visual methods. Lampooning of Romanian territorial demands appeared, for example, in one of the caricatures mentioned above, when "hungry Romanians" were shown standing in front of a Hungarian butcher shop window with their tongues hanging out. At the shop window, the names of Transylvanian counties were written on sausages, and the hungry Romanians were depicted as wanting to "devour" all the sausages, which was a reference to the Romanian territorial claim to Transylvania (see figure 1). Gluttony is one of the seven deadly sins, and therefore the motif of undue hunger was also an appropriate way to pass judgement on demands for territory.

In Černokňažnik a caricature that included Hungarian territory was published to show rejection and judgement of what they considered increasing Hungarian selfconfidence (figure 11). In this cartoon, the globe was depicted in a way suggesting the entire world would be occupied by Hungary: no other continents or countries are visible, and Budapest is placed in the middle of the globe. The "Hungarian globe" was a phrase used toward the end of the nineteenth century to mock Hungarian chauvinism, and the nonHungarian satirical press used this symbol often. ${ }^{53}$ In the caricature, the national minority groups are shown supporting the globe on their shoulders with Hungarians and Jews dancing on it. This representation recalls medieval traditions: in the medieval and early modern periods the social orders of the three estates of the Church, nobility, and peasantry supported the globe. The function of the first two was to maintain a world order that was not beneficial for the third, and the church or the king stood on top of the globe. This illustration also references traditions from antiquity: Zeus punished Atlas by making him support the heavens on his shoulders. ${ }^{54}$ The caricature further addresses the migration of Jews from Galicia to Hungary, and the subsequent increase in the number of Jewish-Hungarian inhabitants in contrast to the Slovaks, since many Slovaks emigrated to the United States to overcome their overly disadvantageous economic circumstances. ${ }^{55}$

In the Serbian satirical magazine, the phrase "Hungarian globe" also occurs in its cartoons to criticise the Hungarian idea of the great Hungarian Empire and the assimilation of Jews. ${ }^{56}$ In Vrač pogađač, a map of Hungarian national groups serves to illustrate the situation from the Serbian point of view: in the middle of the map there is a small Hungarian territory, and the other parts of Hungary (and also some parts of present-day Hungary after the Treaty of Trianon in 1920) are marked as territories of non-Hungarian national groups (figure 12).

\section{Conclusion}

To summarise the results of the analysis presented in this paper, it may be concluded that images of the Other and the Self are depicted via humorous or ironic methods in accordance with stereotypes privileged by the Hungarian and the non-Hungarian satirical press. The caricatures are effectively distinguishable, and the images can be connected to the processes of nation building process and shaping "enemies". The caricaturists exploited

\footnotetext{
Tóth 1895: 346.

Langemeyer 1984: 221; Hoppál, ed. 1988: 654.

Kövér 1982: 109-115.

Vrač pogađač, 15 March 1898, 54.
} 
a wide range of tools to reach this goal: They used discrete variations in composition to express subordination and dominance (short vs. tall, animalised vs. human); they played with the possibility of what should be placed in the centre of the picture; they contrasted the beautiful with the grotesque, the good with the bad, the civilised with the barbaric, and the human with the animal; and they depicted these characteristics in extremely schematised ways. The Hungarian and non-Hungarian satirical magazines both emphasised and referenced the physicality, traits and characteristics of the Other as the opposite of those that they had self-determined to be their own inner and outer features and habits.

These examples amply illustrate that the Hungarian and the non-Hungarian satirical press contrasted the "us" and "them" groups through similar mechanisms: the group they tried to distinguish themselves from was given negative external (e.g. distortion of the body or face) and internal (forceful, lazy, oppressive) characteristics. The non-Hungarian comics mocked the idea of the Hungarian national state, its historical traditions, and its political goals. The Hungarian press, on the other hand, poked fun both at the national minority groups' political demands (autonomy, use of their mother tongue) and at the traits they felt were personified by the minority non-Hungarian nationalities in Hungary.

Long-standing and novel components of stereotypes can be found in both nonHungarian and Hungarian publications: the older notions were rooted in feudalism and in the ethnic consciousness, while the new ones were products of modernity and nationalism. Thus, the grounded nature of the separation of ethnic roots and modern nations is evidenced in the caricatures, as is the existence of two concurrent and equally robust viewpoints of nationalism. The system of stereotypes was built on contrasts that prevailed in medieval societies (land owners as oppressors, serfs as the oppressed). These typecasts were subsequently transformed into modern national conflicts. Thus, the old stereotypes had to be reworded to serve the goals of emergent nationalism. They could perform the tasks required to attain the objectives of the non-Hungarian national movements by satirising the aims of the Hungarian national state and by evoking a collective memory of Hungarian history. The non-Hungarian national movements were able to emphasise their raison d'étre by representing their own groups as martyrs.

Similarly, the Hungarian satirical magazines questioned the validity of any of the non-Hungarian national movements' demands through images of animalised Serbs, dehumanised Romanians, and inferior Slovaks. The lampooning cartoons thus strengthened the idea of the construction of a great Hungarian Empire without national minorities. Thus, such ridiculing depictions of the "enemies" based on stereotypes and prejudices were able to function as instruments of Hungarian national propaganda. At the end of the nineteenth century, the stereotypes and symbols became increasingly more aggressive as the nationalism of both the Hungarians and the non-Hungarian groups grew more potent.

These stereotypes were not based on common rationality; instead, the simplification and paring down of people into exaggerated attributes triggered an emotional motivation that became determinant. Therefore, it is crucial to investigate the mechanisms at work in the construction of these stereotypical characteristics. These type cast depictions expressed the long and complicated relationship of the nationalities to one another and articulated the direction in which the relationship was evolving. The external visual elements and the inner characteristics of the stereotypes, as discussed in this paper, both influenced the propagated 
image of the Self and the Other even in the period between the two world wars. These means of representation and the supposed characteristics of the Self and the Other survived for a long time after their historical validity.

The present investigation also demonstrated that the ethnic caricatures and the captions (and texts) of the cartoons reveal insights that are similar to the findings Takovski presented in his paper. One can find universal stereotypes (lazy, barbaric, or stupid, but never canny in the Hungarian case) in order to differentiate the "us" from the "them". "Ethnicised" qualities are also posited: according to the Hungarian satirical magazines, the Serbs (and Romanians) are aggressive and the Slovaks drink too much schnapps; but the non-Hungarian cartoons presented the Hungarians as belligerent. Finally, real ethnic stereotypes are present, too: names, languages, national histories, territories, and national costumes are all ridiculed in the comics in illustrations and in texts and captions.

The present paper thus reveals that the identification of "us" as a separate group requires more than a common historical memory; it needs the construction of another (an Other) group, one that represents one's "enemy". The shaping of the image of the enemy is therefore closely linked to the process of nation building.

\section{REFERENCES:}

Cooper, J. C. Illustriertes Lexikon der traditionellen Symbole, Wiesbaden: Drei Lilien, 1986.

Davies, Ch. Ethnic humor around the world, A comparative analysis, Bloomington/Indianapolis: Indiana University Press, 1990.

Farkas, T. 'Jewish surname changes in Hungary $\left(19^{\text {th }}-20^{\text {th }}\right.$ century)', in: E. W. S. Ahrens, and A. Lapierre (eds.), Names in multi-lingual, multi-cultural and multi-ethnic contact: Proceedings of the 23rd International Congress of Onomastic Sciences, 17-22 August 2008, Toronto: York University, 2009, 375-384.

. 'Names and Hungarian humour', in: A. Litovkina T. et al. (eds), Hungarian Humour, Humor and Culture 3, Kraców: Tertium, 2012, 343-351.

Fuchs, E. and Kraemer, H. Die Karikatur der europäischen Völker vom Altertum bis zur Neuzeit, Berlin: Hofmann, 1901.

Fuchs, E. Die Juden in der Karikatur, Ein Beitrag zur Kulturgeschichte, München: Albert Langen, 1921.

Grünwald, B. A Felvidék, Politikai tanulmány [Upper Hungary: A political study], Budapest: Ráth Mór, 1878.

Hajdú, M. Általános és magyar névtan [General and Hungarian onomastics], Budapest: Osiris, 2003.

Holotík, L. 'Die Slowaken', in: A. Wandruszka and P. Urbanitsch (eds.), Die Habsburgermonarchie 1848-1918, vol. 3/2, Die Völker des Reiches, Wien: Österreichische Akademie der Wissenschaften, 1980, 775-800.

Hoppál, M. ed., Mitológiai enciklopédia [Encyclopaedia of mythology], vol. 1, Budapest: Gondolat, 1988.

Hroch, M. 'From national movement to the fully-formed nation, The nation building process in Europe', New Left Review, 2, 1993, 5-20.

Illyefalvi vitéz, G. ed., Magyarország statisztikája [Statistics of Hungary], Budapest: Politzer, 1904.

Koselleck, R. Az aszimmetrikus ellenfogalmak történeti-politikai szemantikája (Original: Zur historisch-politischen Semantik asymmetrischer Gegenbegriffe), Budapest: Jószöveg, 1997. . 'Ellenségfogalmak' [Concepts of the enemy], in: M. Szabó (ed.), Az ellenség neve [The name of the enemy], Budapest: Jószöveg, 1998, 12-23. 
Kövér, Gy. Iparosodás agrárországban, Magyarország gazdaságtörténete: 1848-1914 [Industrialisation in an agrarian country, The history of Hungarian economy, 1848-1914], Budapest: Gondolat, 1982.

Krekovičová, E. and Panczová, Z. 'Visual representations of the "Self" and "Others": Images of the traitor and the enemy in Slovak political cartoons, 1861-1910', in: D. Demski, I. Sz. Kristóf, and K. Baraniecka-Olszewska (eds.), Competing eyes: Visual encounters with alterity in Central and Eastern Europe, Budapest: L'Harmattan, 2013, 462-487.

Laineste, L. 'Targets of Estonian ethnic jokes within the theory of ethnic humour (Ch. Davies)', Folklore, 29, 2005, 7-24.

Laineste, L. and Fiadotava, A. 'Globalisation and ethnic jokes: A new look on an old tradition in Belarus and Estonia', European Journal of Humour Research, 5, 2017, 85-111.

Langemeyer, G. ed., Das Bild als Waffe, Mittel und Motive der Karikatur in fünf Jahrhunderten, München: Prestel, 1984.

Maitz, P. and Farkas, T. 'Der Familienname als Nationalsymbol. Über den Untergang deutscher Familiennamen im Ungarn des 19. Jahrhunderts', Zeitschrift für germanistische Linguistik, 2, 2008, 163-193.

Pădurean, F. 'When Ytzig met Shtrul: On schmoozing and Jewish conspiracy in Romanian Art' in D. Demski, I. Sz. Kristóf and K. Baraniecka-Olszewska. (eds.), Competing eyes: Visual encounters with alterity in Central and Eastern Europe, Budapest: L' Harmattan, 2013, 488-514.

Ripa, C. Iconologia azaz különféle képek leirása, amelyeket az antikvitásból feltalált vagy tulajdon leleményével megalkotott és magyarázatokkal ellátott a perugiai Cesare Ripa [Iconologia or the description of various pictures recovered from antiquity or made up and explained by Cesare Ripa of Perugia], Budapest: Balassi, 1997.

Smith, A. D. Historiographical debates about ethnicity and nationalism, Cambridge: Polity, 2000.

Slíz, M. 'The aim of naming in parody', in: A. Litovkina T. at al. (eds), Hungarian Humour, Humor and Culture 3, Kraców: Tertium, 2012, 355-365.

Szabó, M. 'Invasion of "Judeo-Magyars"? The Hungarian Millennium of 1896 in the anti-Semitic caricature', in: D. Demski, I. Sz. Kristóf and K. Baraniecka-Olszewska (eds.), Competing eyes: Visual encounters with alterity in Central and Eastern Europe, Budapest: L'Harmattan, 2013, 212-229.

Szalisznyó, L. „, Irjátok a mi tollatokra jön”. Egressy Gábor családi levelezése (1841-1865). ["Write As It Comes To Your Pen”, Correspondence In The Family Of Gábor Egressy (1841-1865)], Csokonai Könyvtár: Források 19 [Csokonai Library, Sources 19], Debrecen: Debrecen University Press, 2017.

Szarka, L. Szlovák nemzeti fejlödés-magyar nemzetiségi politika, 1867-1918 [Slovak national development and Hungarian policy regarding national minorities, 1867-1918], Bratislava: Kalligram, 1995.

Takovski, A. 'Extending ethnic humour theory: Genuine vs. functional ethnic joke scripts' European Journal of Humour Research, 6, 2018, 60-80.

Tamás, Á. 'Zsidó személynevek és névmagyarosítás a 19. század végi magyar élclapokban' [Jewish personal names and the Hungarianization of names in the Hungarian satirical magazines in the late 19th century], Névtani Értesitö, 34, 2012, 41-48.

Nemzetiségek görbe tükörben, 19. századi nemzetiségi sztereotípiák Magyarországon [National groups in twisted mirror, National stereotypes in Hungary in the 19th century], Pozsony: Kalligram, 2014.

Tóth, B. Szájrul szájra [From mouth to mouth], Budapest: Athenaeum, 1895.

Vajda, J. Magyarság és nemzeti önérzet, Kóros áramok [Hungarians and national pride, Abnormal streams], Budapest: Singer \& Wolfner, 1896. 


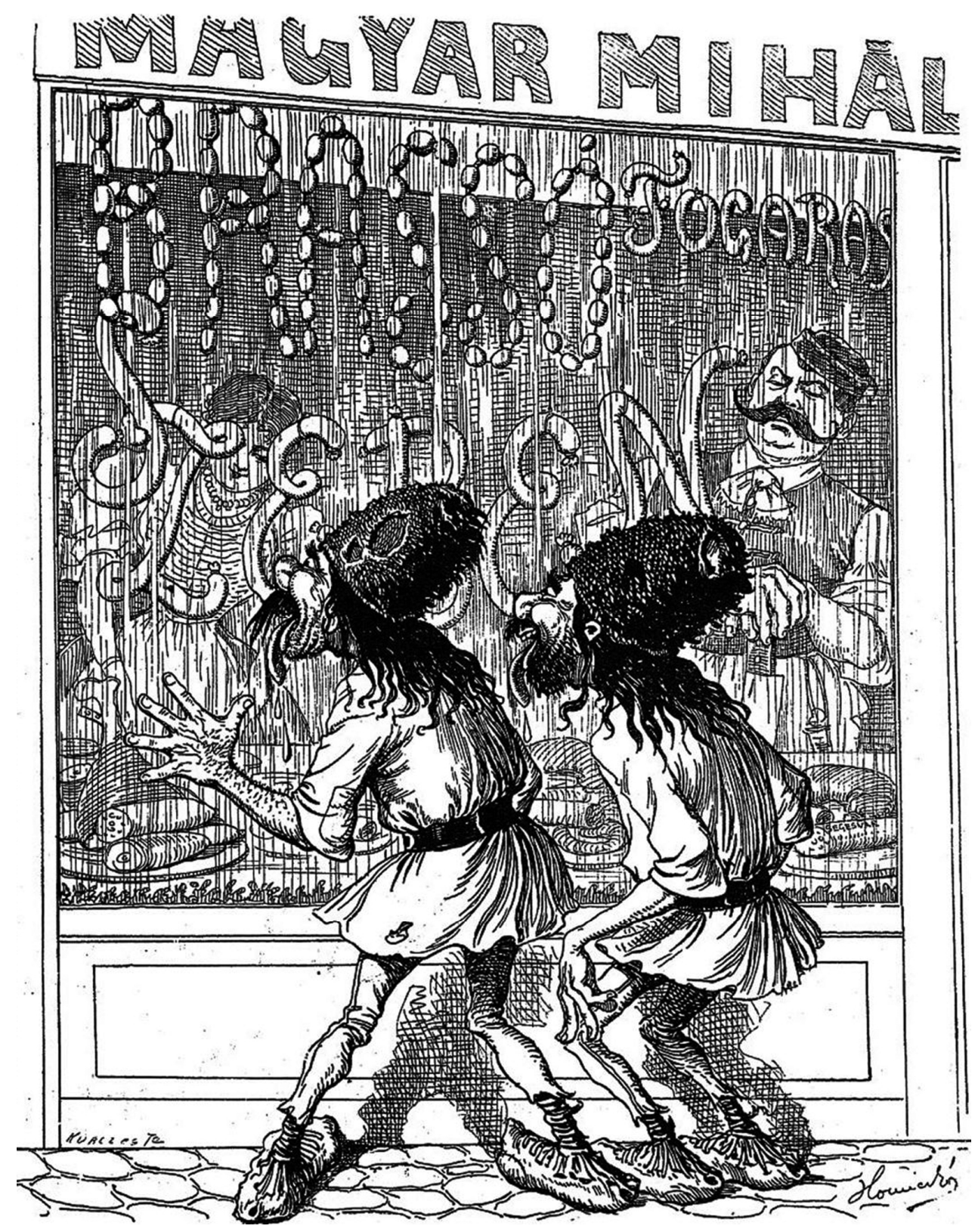

Fig. 1

"Hungry Romanians - in front of the butcher shop." Borsszem Jankó, 22 May 1898, 9. 


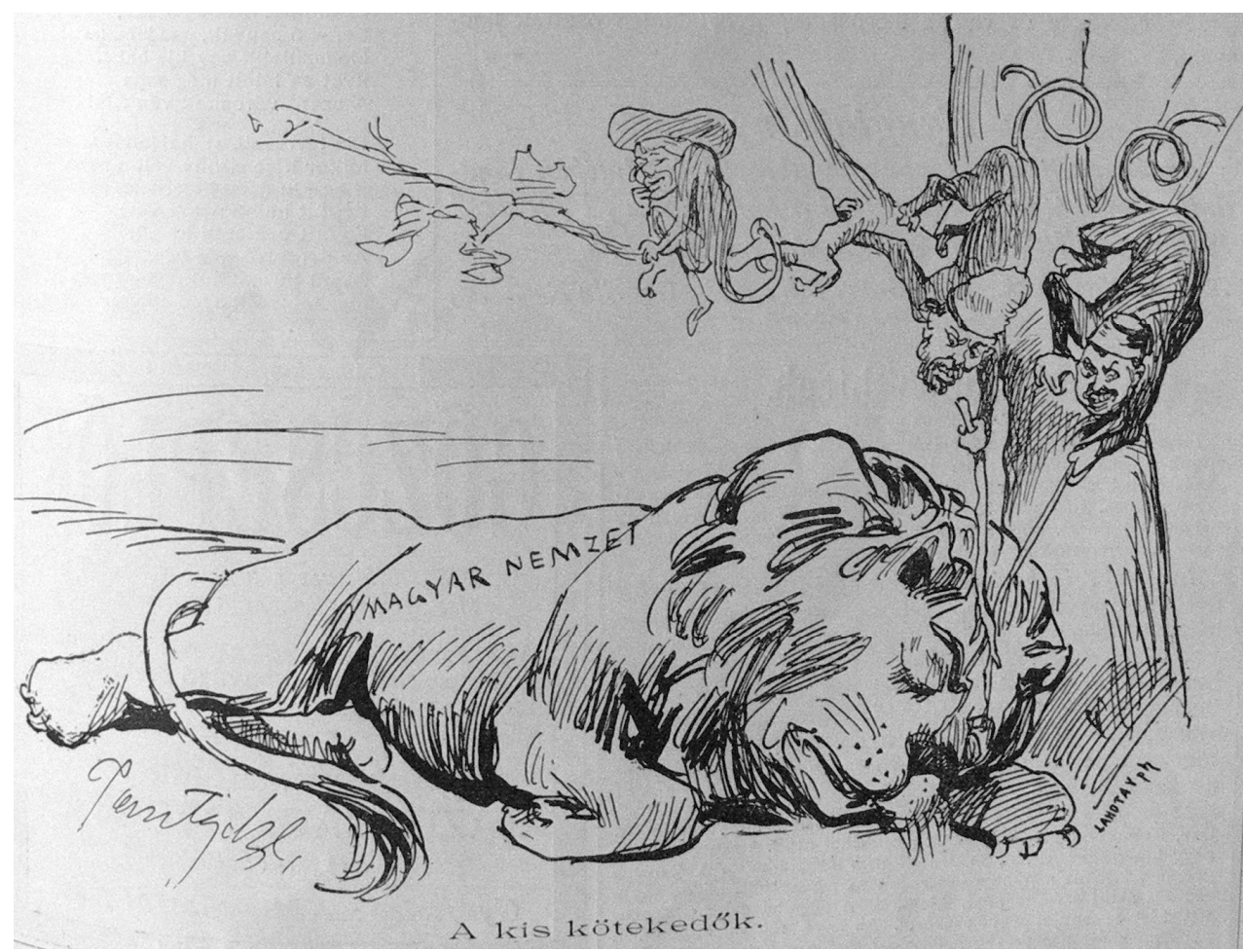

Fig. 2

"The small aggressors."

Borsszem Jankó, 15 August 1896, 328. 


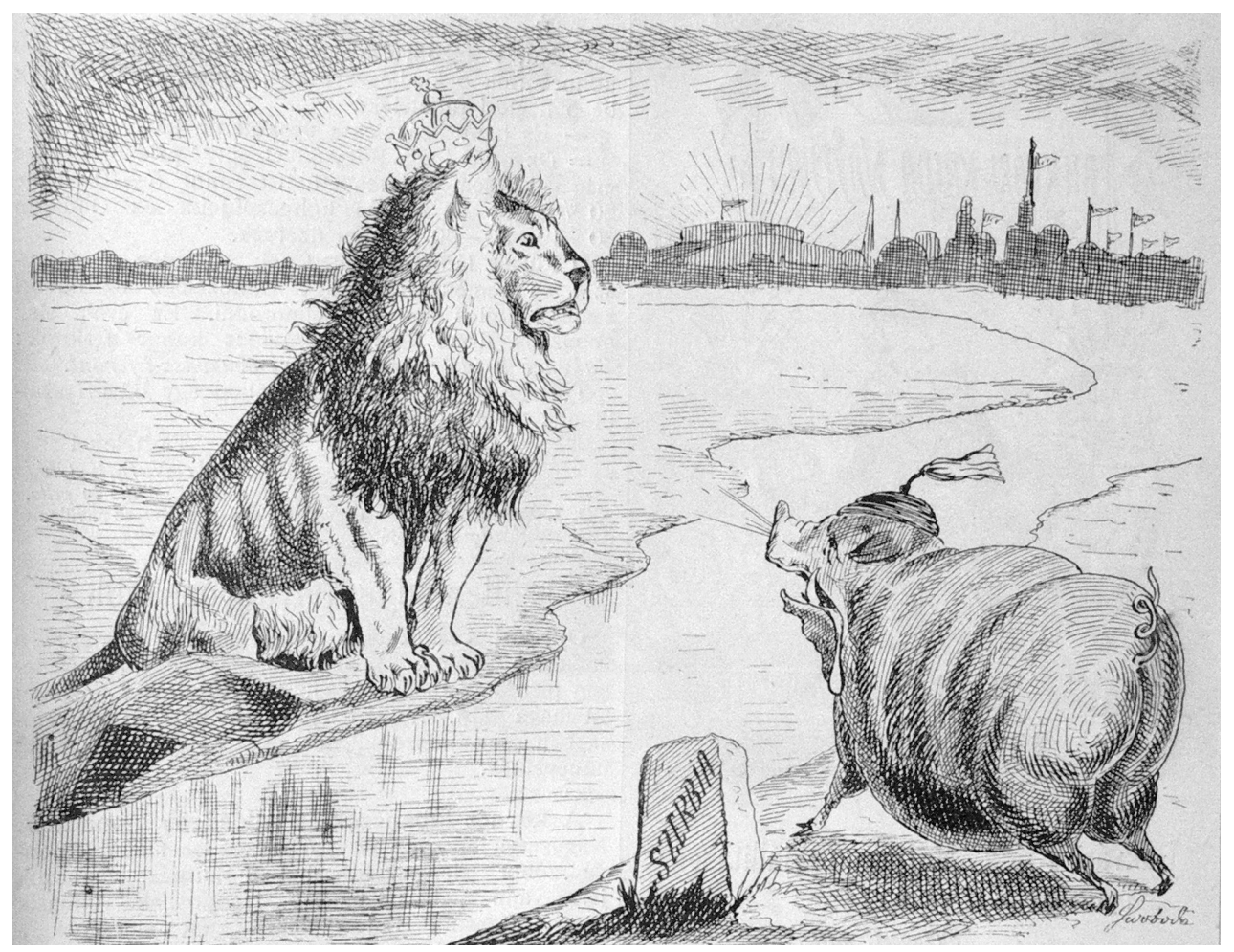

Fig. 3

"The Serbian pig/insult.

[In Hungarian, the word sertvés is a blend of sertés "pig" and sértés "insult", hence the pun of the words "pig" and "insult"]

Who would have believed that pigs' and dogs' anger exists in the world as well?" Üstökös, 10 May 1896, 247. 


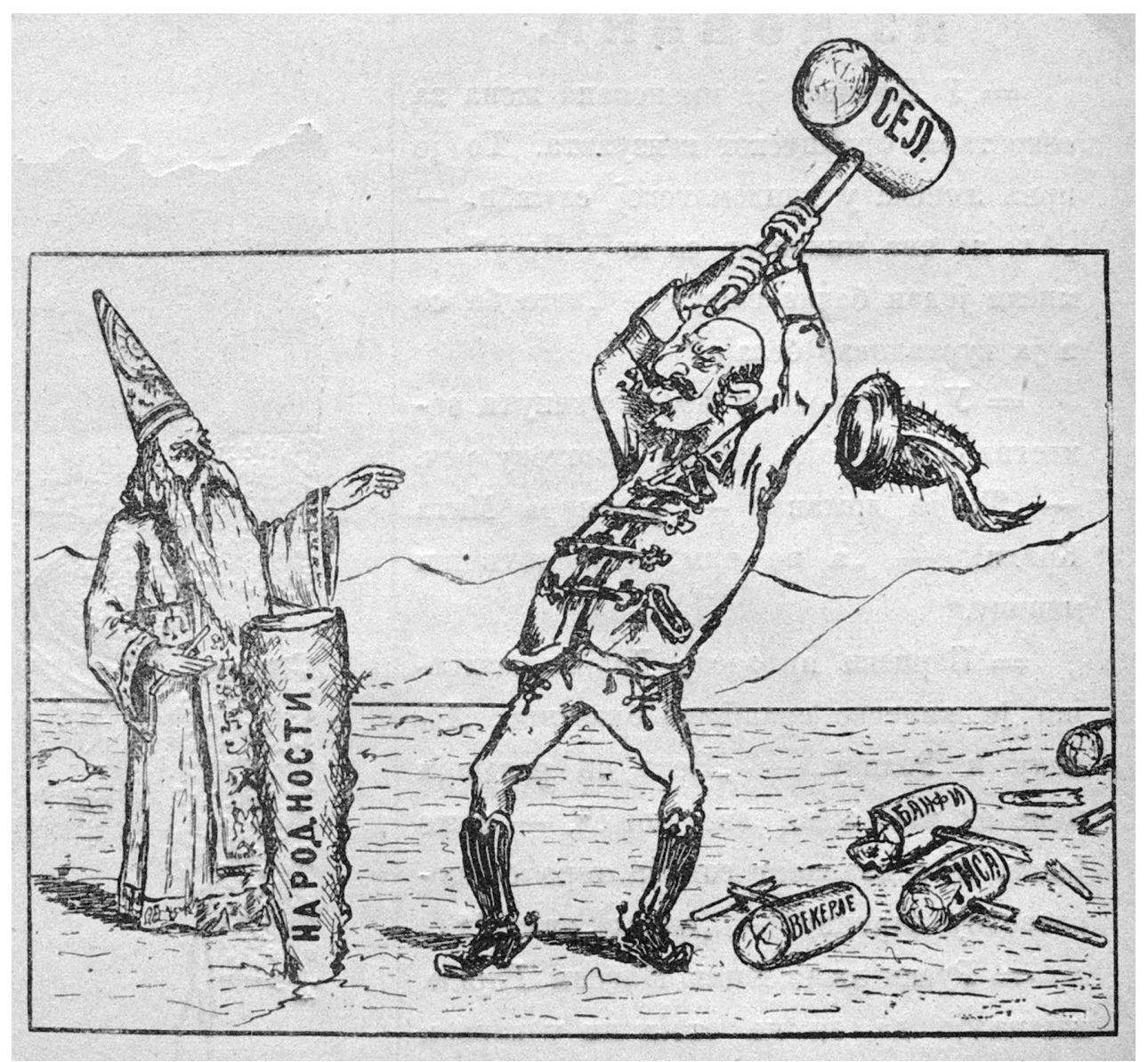

Fig. 4

"Goddamit! I have to knock it into the ground!

A weak frog. Much bigger hammers broke here already." Vrač pogađač, 24 March 1902, 35. 


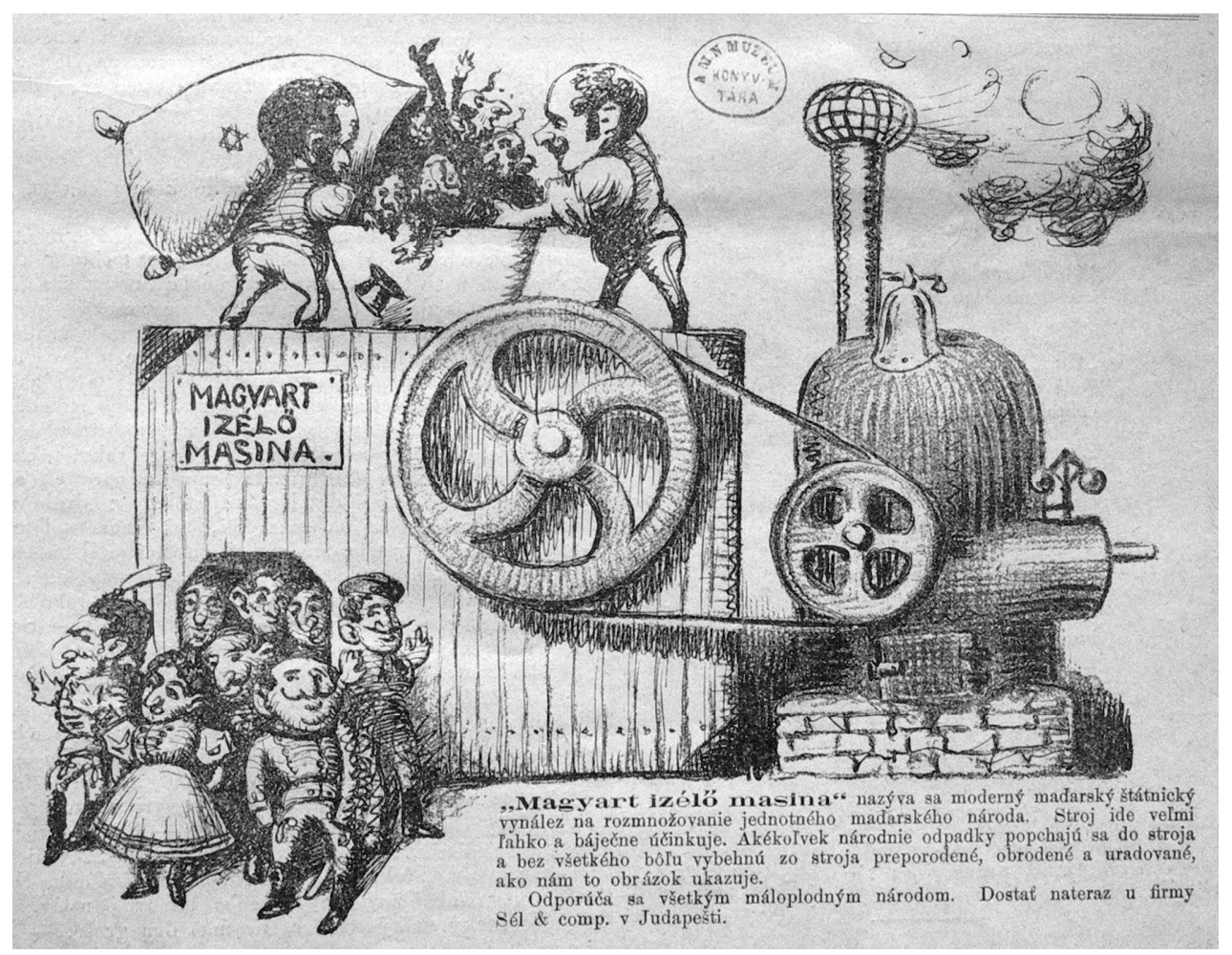

Fig. 5

Černokňažnik, 25 January 1901, 1. 


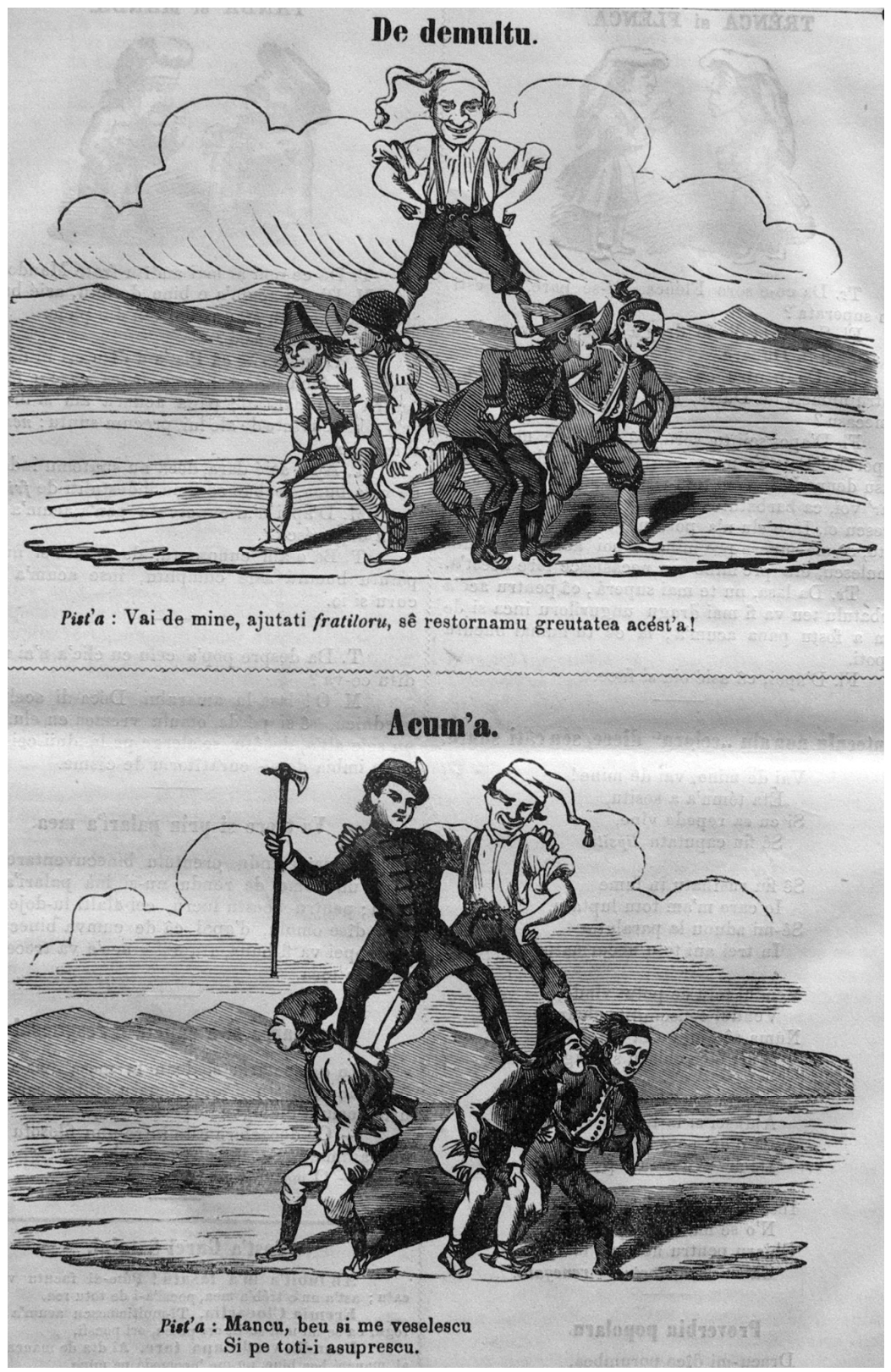

Fig. 6

"Earlier. Pista: Please, help me brothers to throw off this weight! Now. Pista: I am eating, drinking and being merry, and oppress everybody." Gur'a Satului, 30 October 1868, 148. 


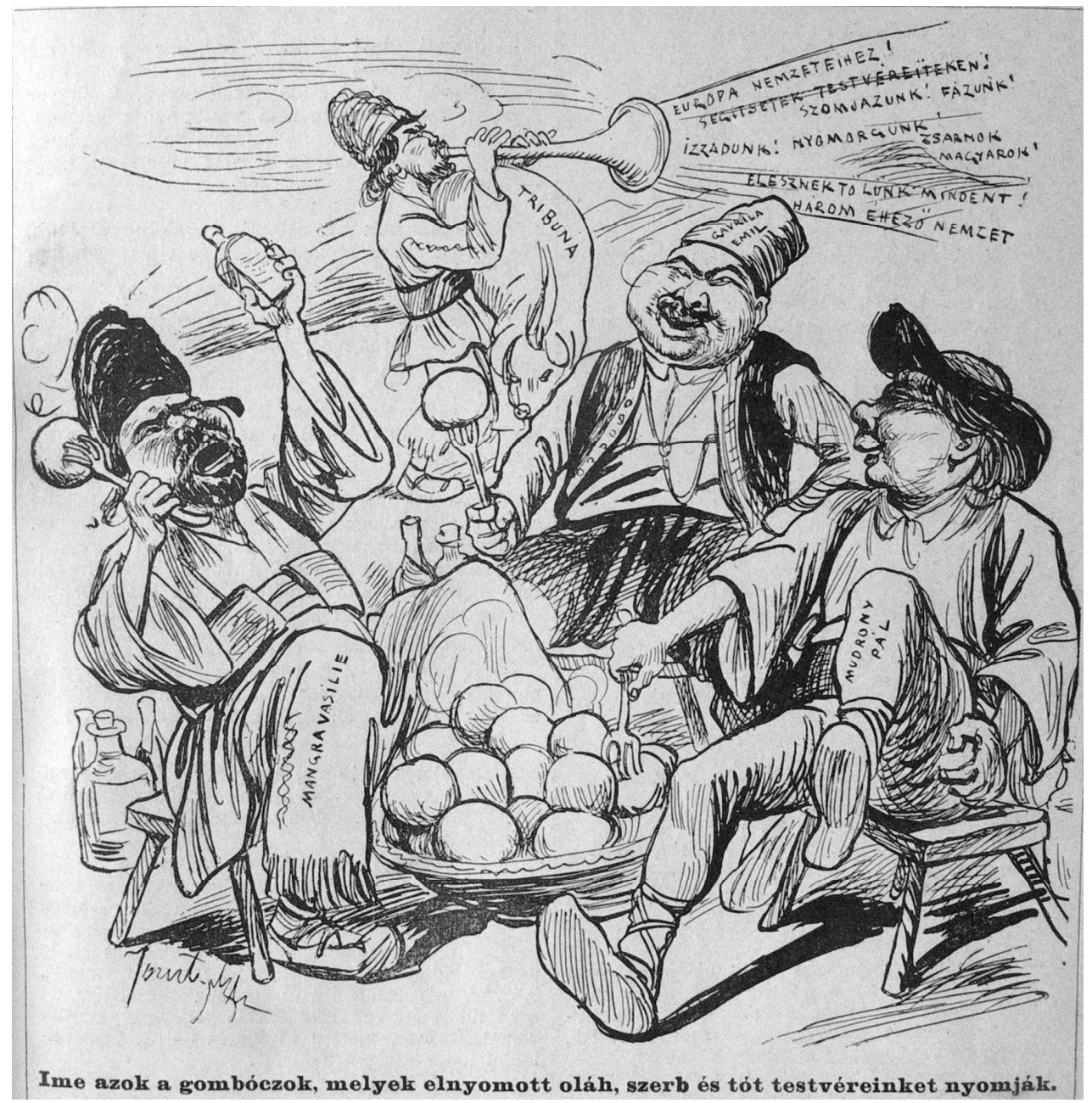

Fig. 7

"Here are the dumplings repressing our Romanian, Serbian and Slovak brothers." Üstökös, 4 August 1895, 365. 


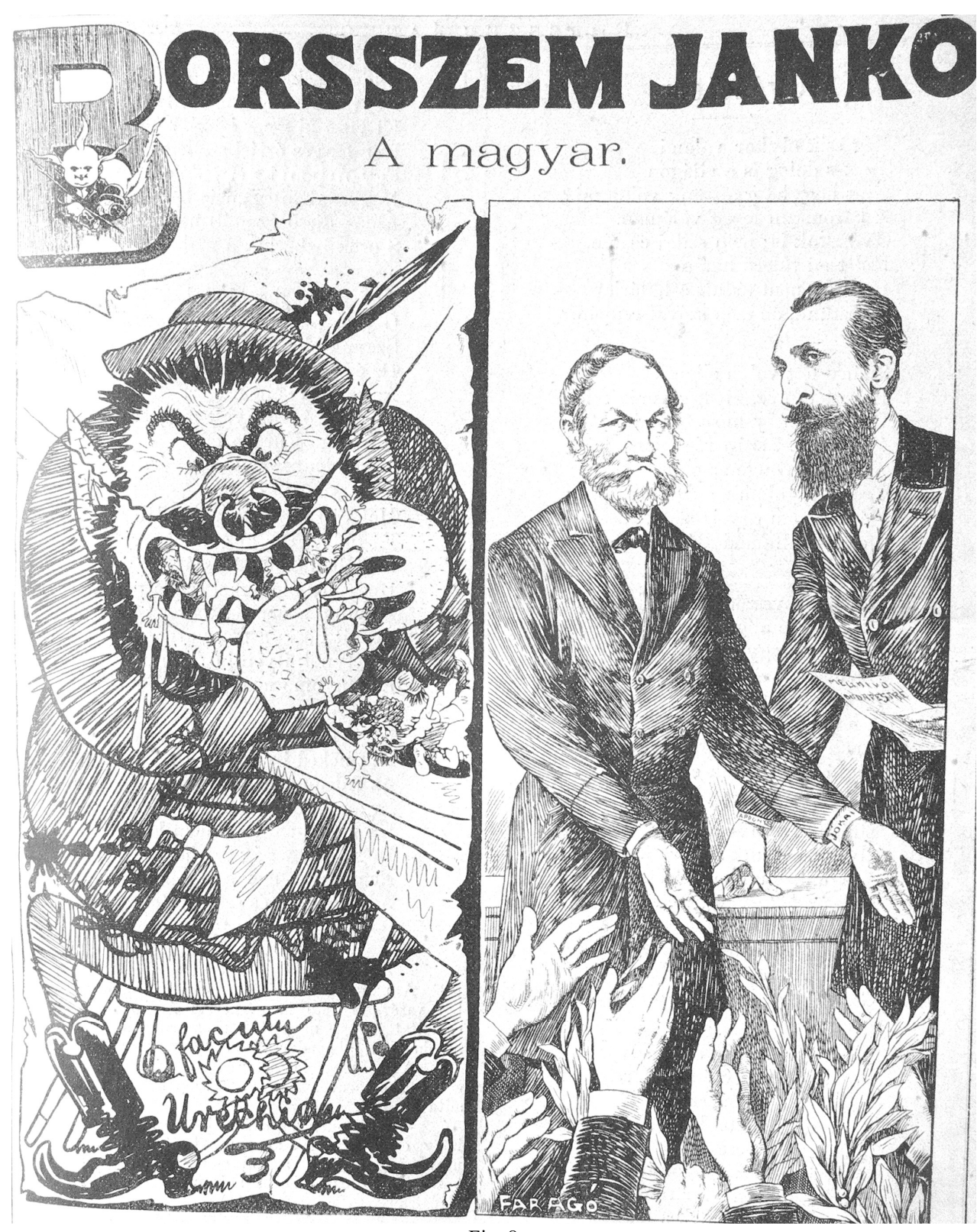

Fig. 8

"The Hungarian. How Urechia painted him in Brussels. The way he was seen in reality." [Vasilie Alexandrescu-Urechia (1834-1901) Romanian historian and politician, held a great number of speeches against the Hungarian oppression.] Borsszem Jankó, 25 August 1895, 1. 


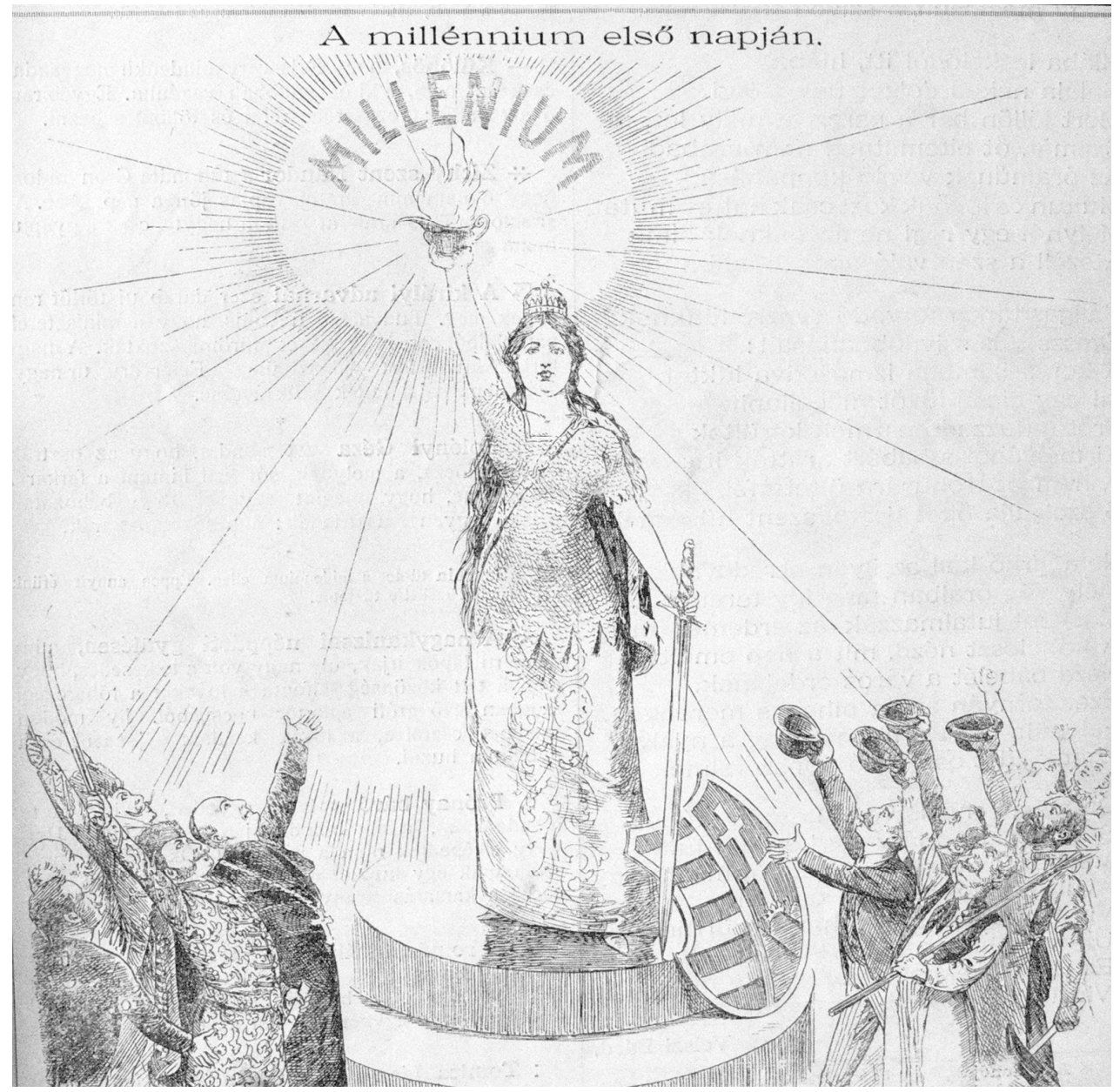

Fig. 9

"On the first day of the Millennium" Üstökös, 3 May 1896, 233. 


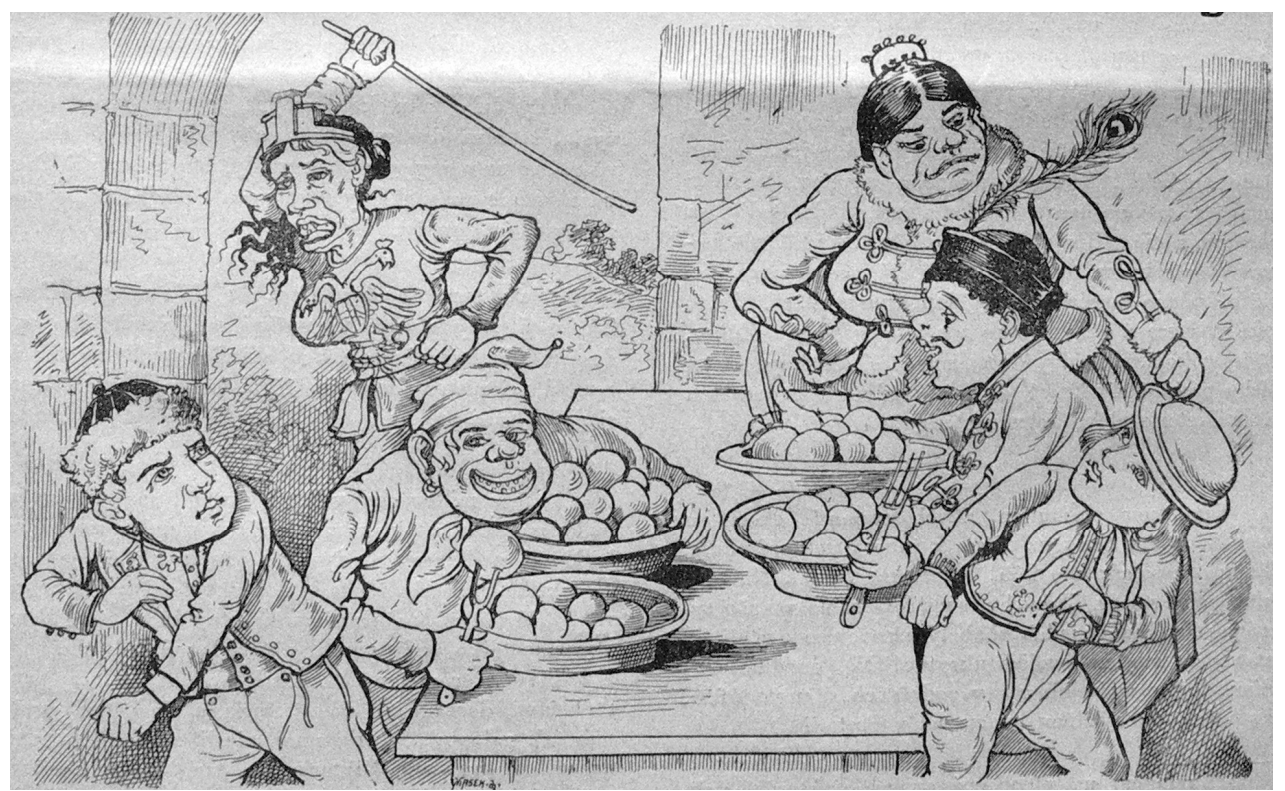

Fig. 10

"Two good and fair mothers.

Mother Cis. Godless Vaško! I will see whether you give Michel to eat!

Vašek: But this Michel took my portion, too, mother!

Mother Cis: Here is your portion, you godless!

Mother Trans: Wait, I will see whether you give Pistike to eat!

Janko: But mother, Pista took my portion, too!

Mother Trans: Here is your portion, you good-for-nothing!"

Černokňažnik, 25 November 1899, 81. 


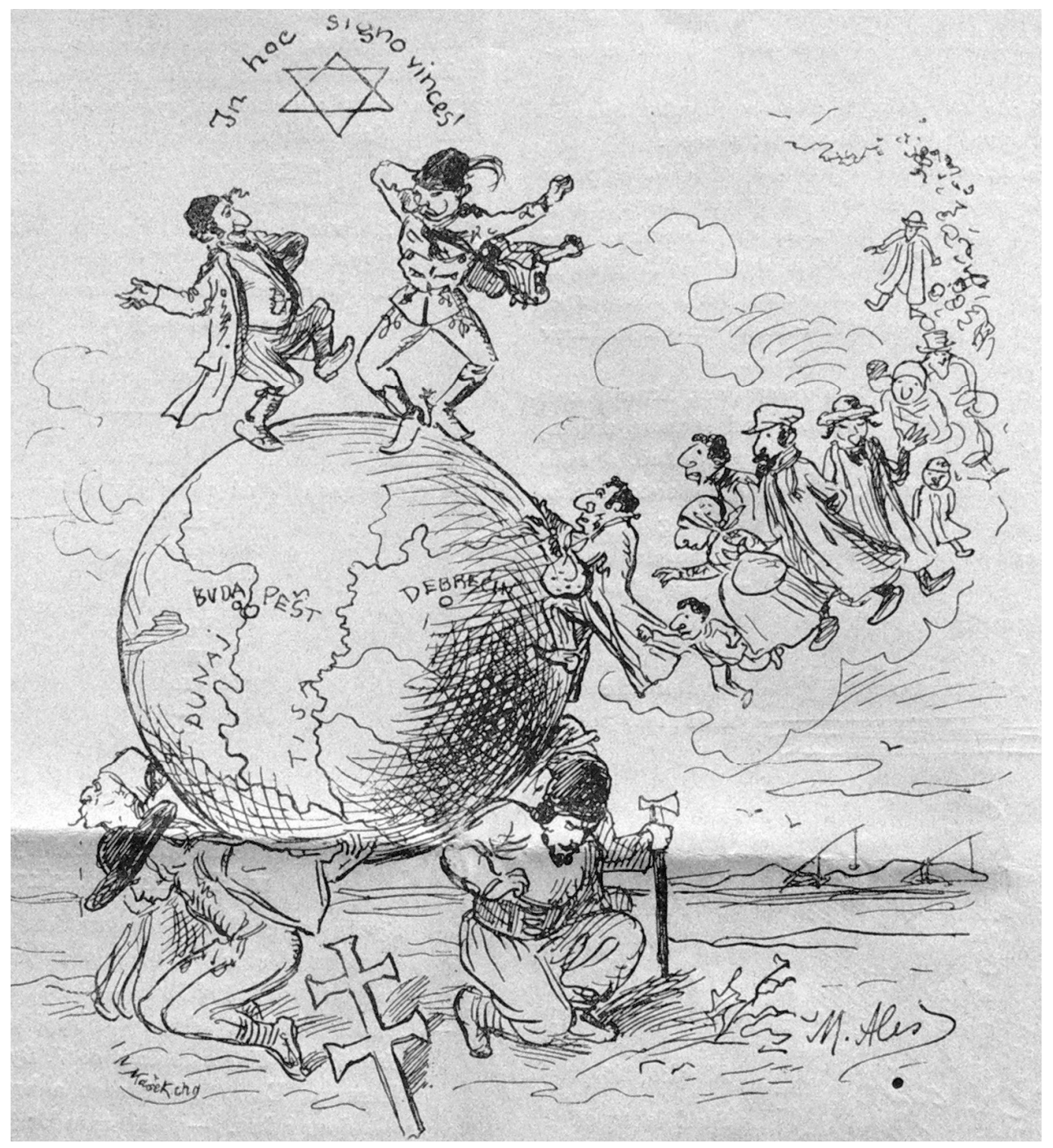

Fig. 11

"The occupation of Pan-Hungary in 1896.

What will happen if all of them get up, and these four pillars break?" Černokňažnik, 25 March 1896, 20. 


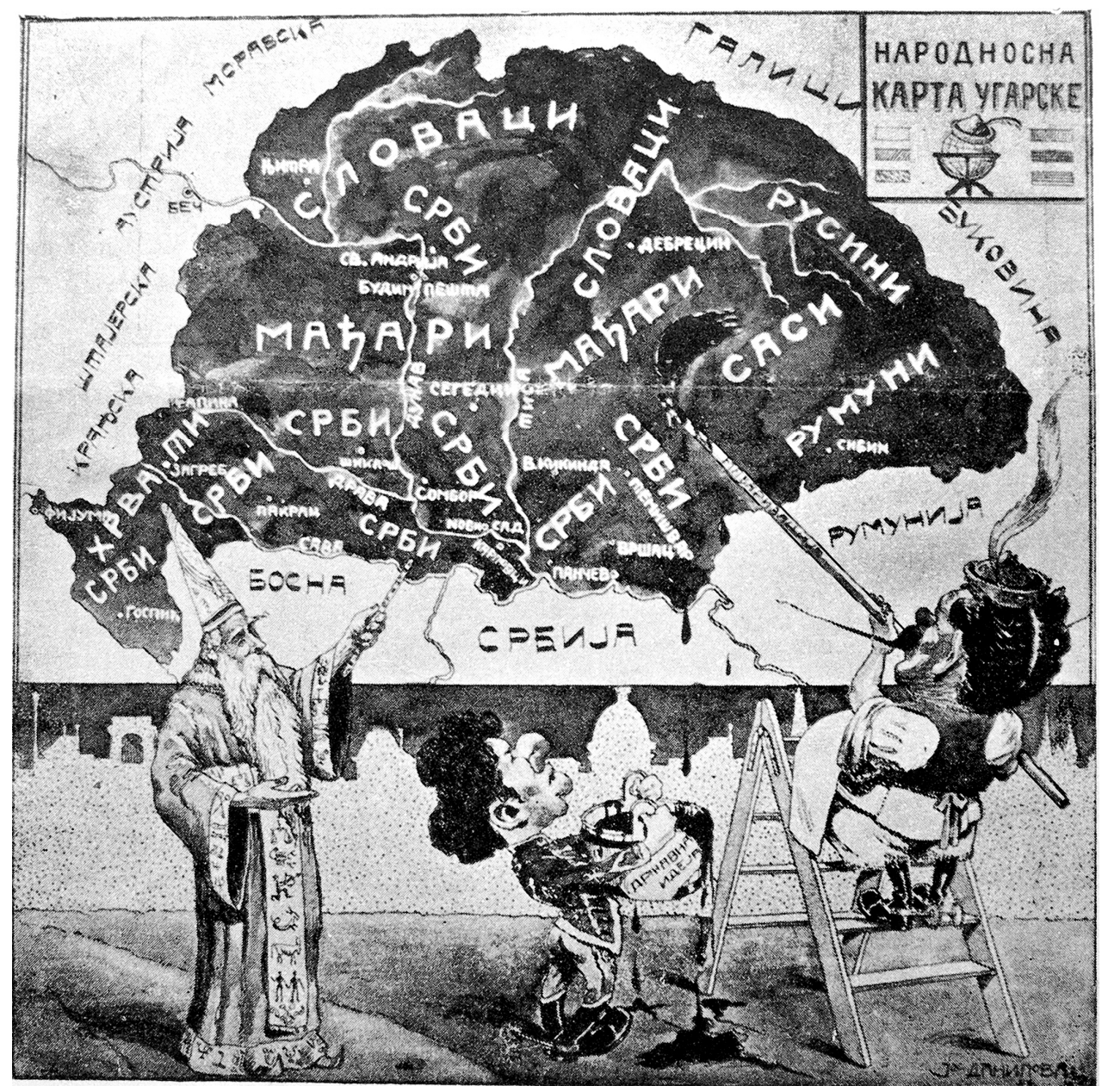

Figure 12

"Please hold it just for a little while and help me, brother Smulo.

In order to darken that small territory which bothers our eyes so much!

You are painting it in vain, making it darker is futile, for white will never be black, Do you think you, Uncle Magyar, can make it!"

Vrač Pogađač, 15 January 1898, 17. 


\title{
АГНЕШ ТОМАШ \\ Универзитет у Сегедину, Одсек за модерну историју Мађарске \\ ИСМЕВАЊЕ ИЗГРАДЊЕ НАЦИЈЕ И ИДЕНТИТЕТА. АНАЛИЗА КАРИКАТУРА У МАБАРСКИМ, РУМУНСКИМ, СРПСКИМ И СЛОВАЧКИМ САТИРИЧНИМ ПЕРИОДИКАМА ОД СРЕДИНЕ ДО КРАЈА ХІХ ВЕКА
}

\begin{abstract}
Резиме
Рад представља упоредну анализу карикатура објављених у мађарским (Üstökös, Borsszem Jankó), српским (Бич, Врач погађач), румунским (Gur'a Satului) и словачким (Černokňažník) хумористичким листовима у другој половини XIX века. Намера је да се покаже дубинска веза између идентитета, изградње нације и хумора.

Поређење које се спроводи у раду користи и допуњује дефиницију етничког језгра коју је дао Ентони Д. Смит, и позива се на теорију етничког хумора Кристија Дејвиса. Анализа карикатура посвећена је следећим аспектима: именима себе и другога, елементима културе и традиције (језици, навике, религије, претпостављене особине, одевање и телесне одлике), симболима себе и другога, историјским сећањима и митовима о заједничком пореклу себе и других, и дефиницији ‘наших’ насупрот ‘њиховим’ територијама и отаџбинама.

Слике о другима и себи су дочараване путем хумористичких или ироничких метода, а у складу са стереотипима којих су се држали мађарски и не-мађарски забавни листови. О обема врстама публикација могу се пронаћи и дуготрајне и нове компоненте стереотипа. Ови стереотип нису били засновани на рационалности, већ су поједностављивање и поистовећивање људи са преувеличаним атрибутима производили емоционалну мотивацију која је постајала одређујућа. Стога је кључно истраживати механизме конструкције стереотипних карактеристика. Ова врста представа је изражавала дуготрајне и сложене међусобне везе поменутих националности и артикулисала је правац у којем су односи даље развијани.

Кључне речи: национализам, изграђивање нације, карикатуре, сатирични часописи, исмевање ,других“.
\end{abstract}

